Article

\title{
The Effect of CO Partial Pressure on Important Kinetic Parameters of Methanation Reaction on Co-Based FTS Catalyst Studied by SSITKA-MS and Operando DRIFTS-MS Techniques
}

\author{
Michalis A. Vasiliades ${ }^{1}{ }^{\mathbb{D}}$, Konstantina K. Kyprianou ${ }^{1} \mathbb{1}$, Nilenindran S. Govender ${ }^{2}$, \\ Ashriti Govender ${ }^{2}$, Renier Crous ${ }^{2}$, Denzil Moodley ${ }^{2}$ and Angelos M. Efstathiou ${ }^{1, *}$ (I) \\ 1 Heterogeneous Catalysis Laboratory, Chemistry Department, University of Cyprus, 2109 Nicosia, Cyprus; \\ michael_vasiliades@hotmail.com (M.A.V.); kyprianou.konstantina@ucy.ac.cy (K.K.K.) \\ 2 Sasol Group Technology, 1 Klasie Havenga Street, Sasolburg 1947, South Africa; \\ gregory.govender@gmail.com (N.S.G.); ashriti.govender@gmail.com (A.G.); renier.crous@sasol.com (R.C.); \\ Denzil.Moodley@sasol.com (D.M.) \\ * Correspondence: efstath@ucy.ac.cy; Tel.: +357-22-892776
}

Received: 4 May 2020; Accepted: 20 May 2020; Published: 22 May 2020

\begin{abstract}
A $20 \mathrm{wt} \% \mathrm{Co}-0.05 \mathrm{wt} \% \mathrm{Pt} / \gamma-\mathrm{Al}_{2} \mathrm{O}_{3}$ catalyst was investigated to obtain a fundamental understanding of the effect of $\mathrm{CO}$ partial pressure (constant $\mathrm{H}_{2}$ partial pressure) on important kinetic parameters of the methanation reaction ( $\mathrm{x} \mathrm{vol} \% \mathrm{CO} / 25 \mathrm{vol} \% \mathrm{H}_{2}, \mathrm{x}=3,5$ and 7 ) by performing advanced transient isotopic and operando diffuse reflectance infrared Fourier transform spectroscopy-mass spectrometry (DRIFTS-MS) experiments. Steady State Isotopic Transient Kinetic Analysis (SSITKA) experiments conducted at $1.2 \mathrm{bar}, 230{ }^{\circ} \mathrm{C}$ after $5 \mathrm{~h}$ in $\mathrm{CO} / \mathrm{H}_{2}$ revealed that the surface coverages, $\theta_{\mathrm{CO}}$ and $\theta_{\mathrm{CHx}}$ and the mean residence times, $\tau_{\mathrm{CO}}$, and $\tau_{\mathrm{CHx}}(\mathrm{s})$ of the reversibly adsorbed CO-s and active $\mathrm{CH}_{\mathrm{x}}-\mathrm{s}\left(\mathrm{C}_{\alpha}\right)$ intermediates leading to $\mathrm{CH}_{4}$, respectively, increased with increasing $\mathrm{CO}$ partial pressure. On the contrary, the apparent activity $\left(\mathrm{k}_{\mathrm{eff}}, \mathrm{s}^{-1}\right)$ of $\mathrm{CH}_{\mathrm{x}}-\mathrm{s}$ intermediates, turnover frequency (TOF, s $\left.{ }^{-1}\right)$ of methanation reaction, and the $\mathrm{CH}_{4}$-selectivity $\left(\mathrm{S}_{\mathrm{CH}}, \%\right)$ were found to decrease. Transient isothermal hydrogenation (TIH) following the SSITKA step-gas switch provided important information regarding the reactivity and concentration of active $\left(\mathrm{C}_{\alpha}\right)$ and inactive $-\mathrm{C}_{\mathrm{x}} \mathrm{H}_{\mathrm{y}}$ $\left(\mathrm{C}_{\beta}\right)$ carbonaceous species formed after $5 \mathrm{~h}$ in the $\mathrm{CO} / \mathrm{H}_{2}$ reaction. The latter $\mathrm{C}_{\beta}$ species were readily hydrogenated at $230{ }^{\circ} \mathrm{C}$ in $50 \% \mathrm{H}_{2} / \mathrm{Ar}$. The surface coverage of $\mathrm{C}_{\beta}$ was found to vary only slightly with increasing $\mathrm{CO}$ partial pressure. Temperature-programmed hydrogenation (TPH) following SSITKA and TIH revealed that other types of inactive carbonaceous species $\left(C_{\gamma}\right)$ were formed during Fischer-Tropsch Synthesis (FTS) and hydrogenated at elevated temperatures $\left(250-550^{\circ} \mathrm{C}\right)$. The amount of $\mathrm{C}_{\gamma}$ was found to significantly increase with increasing $\mathrm{CO}$ partial pressure. All carbonaceous species hydrogenated during TIH and TPH revealed large differences in their kinetics of hydrogenation with respect to the $\mathrm{CO}$ partial pressure in the $\mathrm{CO} / \mathrm{H}_{2}$ reaction mixture. Operando DRIFTS-MS transient isothermal hydrogenation of adsorbed CO-s formed after $2 \mathrm{~h}$ in $5 \mathrm{vol} \% \mathrm{CO} / 25 \mathrm{vol} \% \mathrm{H}_{2} / \mathrm{Ar}$ at $200{ }^{\circ} \mathrm{C}$ coupled with kinetic modeling ( $\mathrm{H}$-assisted $\mathrm{CO}$ hydrogenation) provided information regarding the relative reactivity $\left(\mathrm{k}_{\text {eff }}\right)$ for $\mathrm{CH}_{4}$ formation of the two kinds of linear-type adsorbed CO-s on the cobalt surface.
\end{abstract}

Keywords: FTS; methanation; SSITKA-MS; DRIFTS; hydrogenation; operando studies 


\section{Introduction}

Low-temperature Fischer-Tropsch Synthesis (FTS) is a non-reversible, highly exothermic, and complex reaction (Equation (1)), which has been industrially applied for many decades for using syngas $\left(\mathrm{CO}\right.$ and $\left.\mathrm{H}_{2}\right)$, which is mainly derived from natural gas, biogas, and coal, towards the formation of chemicals and fuels [1-3].

$$
n\left(\mathrm{CO}+2 \mathrm{H}_{2}\right) \rightarrow\left(-\mathrm{CH}_{2}-\right)_{n}+n \mathrm{H}_{2} \mathrm{O}
$$

Great efforts have been made toward understanding the FTS mechanism and kinetically relevant elementary reaction steps in order to design new and improved catalytic materials via different preparation methods with optimum metal loading, particle size, and chemical and structural promoters' composition. Additionally, reaction conditions (e.g., temperature, pressure, reactor-type, syngas ratio) must be tuned for the optimization of selectivity and yield of specific products including olefins, higher hydrocarbons, and alcohols [4-6]. Cobalt supported on different metal oxides (e.g., $\gamma-\mathrm{Al}_{2} \mathrm{O}_{3}, \mathrm{SiO}_{2}$, $\mathrm{TiO}_{2}$ ) and usually promoted with a small amount of noble metal (e.g., Pt, Re) but also of other metals, such as Mn and La, were mainly investigated for low-T FTS [2,7-10].

The use of transient and isotopic techniques coupled with the operando methodology in elucidating FTS mechanisms and kinetics, but also the deactivation of Co-based catalysts is rather limited [11-23]. In particular, Steady State Isotopic Transient Kinetic Analysis (SSITKA) has been recognized as one of the most advanced techniques providing important kinetic information for a heterogeneous catalytic reaction under working reaction conditions, such as the concentration $\left(\mathrm{mol} \mathrm{g}^{-1}\right)$, surface coverage $(\theta)$, mean residence time $(\tau, \mathrm{s})$, and intrinsic site activity $(\mathrm{k})$ of truly active reaction intermediates [14,24-30]. In addition, the intrinsic turnover frequency $\left(\mathrm{TOF}_{\mathrm{ITK}}, \mathrm{s}^{-1}\right)$ based on the concentration of active reaction intermediates measured by SSITKA (not on the total exposed metal surface sites measured by selective chemisorption) leads to the given reaction product and can be estimated $[11,13-16,18,19]$. Density Functional Theory (DFT) computations and microkinetic modelling alone or coupled with DFT [31-41] have been applied over Co-based catalysts for $\mathrm{CO}$ hydrogenation aimed to discriminate rival mechanisms and extract important kinetic parameters of methanation and/or Fischer-Tropsch Synthesis, and identify kinetic reasons for the effects of variation of $\mathrm{H}_{2}$ and/or $\mathrm{CO}$ partial pressure on FTS product distribution. These advanced kinetic studies pointed out that hydrogenation of carbon derived from $\mathrm{CO}$ dissociation (e.g., $\mathrm{CH}_{\mathrm{x}}$ ) appears to be the rate-determining step (RDS), and, by varying the $\mathrm{H}_{2}$ and $\mathrm{CO}$ partial pressures, there are differences in the rates of formation of $\mathrm{CH}_{\mathrm{x}}-\mathrm{S}$ intermediates, which eventually affect their surface lifetime $\left(\tau_{\mathrm{CHx}}, \mathrm{s}\right)$ on the catalytic surface.

The present study aims to provide important mechanistic and kinetic information on the carbon pathway of methane formation at $230{ }^{\circ} \mathrm{C}$ (feed composition: $x$ vol $\% \mathrm{CO} / 25 \mathrm{vol} \% \mathrm{H}_{2} / \mathrm{Ar}, \mathrm{P}_{\mathrm{T}}=1.2$ bar) over a commercially relevant FTS Co-based catalyst (supported on $\gamma-\mathrm{Al}_{2} \mathrm{O}_{3}$ and promoted with $0.05 \mathrm{wt} \% \mathrm{Pt}$ ) [42,43], when the CO partial pressure is varied (36-84 mbar) at a constant hydrogen partial pressure of 0.3 bar. Thus, the effect of $\mathrm{P}_{\mathrm{CO}}$ or syngas ratio $\left(\mathrm{H}_{2} / \mathrm{CO}\right)$ at constant $\mathrm{P}_{\mathrm{H} 2}$ on the following kinetic parameters was investigated.

(i) The amount $\left(\mathrm{N}_{\mathrm{CO}}, \mu \mathrm{mol} \mathrm{g}{ }^{-1}\right)$ and surface coverage $\left(\theta_{\mathrm{CO}}\right)$ of reversibly adsorbed CO-s;

(ii) the amount $\left(\mathrm{N}_{\mathrm{CHx}}, \mu \mathrm{mol} \mathrm{g}{ }^{-1}\right)$ and surface coverage $\left(\theta_{\mathrm{CHx}}\right)$ of active reaction $\mathrm{CH}_{\mathrm{x}}-\mathrm{S}$ $\left(\mathrm{C}_{\alpha}\right)$ intermediates;

(iii) the mean residence time of $\mathrm{CO}-\mathrm{s}\left(\tau_{\mathrm{CO}}, \mathrm{s}\right)$ and active $\mathrm{CH}_{\mathrm{x}}-\mathrm{s}\left(\tau_{\mathrm{CHx}}, \mathrm{s}\right)$ intermediates;

(iv) the turnover frequency leading to $\mathrm{CH}_{4}, \mathrm{TOF}_{\text {chem, }}$ or $\mathrm{TOF}_{\text {ITK }}\left(\mathrm{s}^{-1}\right)$, respectively, estimated based on all Co surface metal atoms or on the active reaction intermediates $\left(\mu \mathrm{mol} \mathrm{g}^{-1}\right)$;

(v) the amount $\left(\mu \mathrm{mol} \mathrm{g}^{-1}\right)$ of inactive carbonaceous species $\left(\mathrm{C}_{\beta}\right)$ formed during FTS $\left(230^{\circ} \mathrm{C}\right)$ readily hydrogenated at $230^{\circ} \mathrm{C}$ in $50 \% \mathrm{H}_{2} / \mathrm{Ar}$;

(vi) the amount $\left(\mu \mathrm{mol} \mathrm{g}{ }^{-1}\right)$ of the refractory carbonaceous species $\left(C_{\gamma}\right)$ formed during FTS but hydrogenated at higher temperatures $\left(230-550{ }^{\circ} \mathrm{C}\right)$; 
(vii) the relative reactivity $\left(\mathrm{k}_{\text {eff }}\right)$ of the various forms of linear-type adsorbed CO-s species formed over the Co surface during methanation after using operando transient DRIFTS-MS coupled with kinetic modelling.

\section{Results}

\section{1. $\mathrm{Co} / \gamma-\mathrm{Al}_{2} \mathrm{O}_{3}$ Catalyst Characterization}

The powder X-ray diffraction (XRD) pattern of the $20 \mathrm{wt} \%$ Co- $0.05 \mathrm{wt} \% \mathrm{Pt}$ supported on Puralox SCCa $\gamma$-alumina carrier after calcination revealed the existence of a $\mathrm{Co}_{3} \mathrm{O}_{4}$ crystalline phase (35.5-38.5 $2 \theta$ range, JCPDS file No. 42-1467) as reported in our previous publication [19]. The mean Co particle size $\left(\mathrm{d}_{\mathrm{Co}}, \mathrm{nm}\right)$ was found to be $10.1 \mathrm{~nm}$ (based on Scherrer equation for $\mathrm{Co}_{3} \mathrm{O}_{4}$ and the derived relationship between $\mathrm{d}_{\mathrm{Co}}$ and $\mathrm{d}_{\mathrm{Co} 3 \mathrm{O} 4}$ particle size), resulting in a Co dispersion with $\mathrm{D}_{\mathrm{Co}}(\%)$ of $9.5 \%$ and a $\mathrm{Co}$ metal surface area of $10.8 \mathrm{~m}^{2} \mathrm{~g}^{-1}$. This result was in good agreement with the $\mathrm{D}_{\mathrm{Co}}(\%)$ estimated from $\mathrm{H}_{2}$ chemisorption/Temperature-programmed desorption (TPD) measurements [19]. TEM studies on the present catalyst [19] showed the formation of agglomerates of individual cobalt particles, which is in agreement with the literature [44]. The textural properties of the present $\mathrm{Co} / \gamma-\mathrm{Al}_{2} \mathrm{O}_{3}$ catalyst were previously reported [19], where the specific surface area (SSA), pore volume $\left(\mathrm{V}_{\mathrm{p}}\right)$, and average pore size $\left(\mathrm{d}_{\mathrm{p}}\right)$ were found to be $88 \mathrm{~m}^{2} \mathrm{~g}^{-1}, 0.21 \mathrm{~cm}^{3} \mathrm{~g}^{-1}$, and $8.8 \mathrm{~nm}$, respectively.

\subsection{SSITKA-MS after $5 \mathrm{~h}$ in FTS}

Figure $1 \mathrm{~A}$ shows transient normalized concentration $(\mathrm{Z})$ response curves of $\mathrm{Kr}$ (tracer gas), ${ }^{13} \mathrm{CO}$, and ${ }^{13} \mathrm{CH}_{4}$ obtained during the SSITKA step-gas switch $3 \mathrm{vol} \%{ }^{12} \mathrm{CO} / 25 \mathrm{vol} \% \mathrm{H}_{2} / \mathrm{Ar}(5 \mathrm{~h}) \rightarrow 3 \mathrm{vol} \%$ ${ }^{13} \mathrm{CO} / 25 \% \mathrm{H}_{2} / 1 \% \mathrm{Kr} / \mathrm{Ar}(\mathrm{t})$ performed at $230{ }^{\circ} \mathrm{C}$ over the $\mathrm{Co} / \gamma-\mathrm{Al}_{2} \mathrm{O}_{3}$ catalyst. It is seen that the $\mathrm{Z}\left({ }^{13} \mathrm{CO}\right)$ transient response curve lags behind that of $\mathrm{Kr}$ due to a measurable concentration (see Equation (5), Section 4.2)) of molecularly and reversibly chemisorbed CO formed after $5 \mathrm{~h}$ in FTS. The $\mathrm{Z}\left({ }^{13} \mathrm{CH}_{4}\right)$ response of gas phase ${ }^{13} \mathrm{CH}_{4}$ clearly lags behind that of $\mathrm{Z}\left({ }^{13} \mathrm{CO}\right)$, and this is attributed to the ${ }^{13} \mathrm{C}$-containing active reaction intermediates formed (following the ${ }^{13} \mathrm{CO}$-s pool), which are sequentially hydrogenated to ${ }^{13} \mathrm{CH}_{4}(\mathrm{~g})$, and the concentration of which is estimated via Equation (6) in Section 4.2.

Figure $1 \mathrm{~A}, \mathrm{~B}$, and Table 1 show that, by increasing the CO feed gas concentration from 3 to $7 \mathrm{vol} \%$ (36 to $84 \mathrm{mbar}$ ), the concentration $\left(\mathrm{N}_{\mathrm{CO}}, \mu \mathrm{mol} \mathrm{g}^{-1}\right)$ and surface coverage $\left(\theta_{\mathrm{CO}}\right)$ of reversibly adsorbed CO-s are increased (see Equations (5) and (7), Section 4.2), which are in agreement with the SSITKA work of $\mathrm{Chen}$ et al. [18]. Figure $1 \mathrm{C}$ presents the effect of $\mathrm{CO}$ partial pressure ( $\left.\mathrm{P}_{\mathrm{CO}}=36-84 \mathrm{mbar}\right)$ and, thus, of the $\mathrm{H}_{2} / \mathrm{CO}$ ratio $\left(3.6-8.3, \mathrm{x} \mathrm{vol} \%{ }^{12} \mathrm{CO} / 25 \mathrm{vol} \% \mathrm{H}_{2} / \mathrm{Ar}\right.$ ) on the transient dimensionless concentration of ${ }^{13} \mathrm{CH}_{4}$ formed during the SSITKA step-gas switch. A clear increasing delay in the appearance of ${ }^{13} \mathrm{CH}_{4}$ with respect to the $\mathrm{Z}(\mathrm{Kr})$ of the tracer is observed. This behavior relates to both the reactivity of $\mathrm{CH}_{X}$-s (named $\mathrm{C}_{\alpha}$ ) active intermediates, which lead to methane and their surface coverage. The amount and surface coverage of the active $\mathrm{CH}_{\mathrm{x}}$-s intermediates, $\mathrm{N}_{\mathrm{CHx}}\left(\mu \mathrm{mol} \mathrm{g}{ }^{-1}\right)$ and $\theta_{\mathrm{CHx}}$, respectively, along with other important kinetic parameters are reported in Table 1 . It is seen that $\mathrm{N}_{\mathrm{CHx}}$ and $\theta_{\mathrm{CHx}}$ are increased to a significant extent with increasing $\mathrm{P}_{\mathrm{CO}}$. An increase by a factor of 2.5 is observed after increasing $\mathrm{P}_{\mathrm{CO}}$ from 36 to 84 mbar.

Figure 2 presents transient rates $\left(\mu \mathrm{mol} \mathrm{g}{ }^{-1} \mathrm{~s}^{-1}\right)$ of exchange, $R_{\mathrm{CO}}^{e x}$ of adsorbed ${ }^{12} \mathrm{CO}$-s with ${ }^{13} \mathrm{CO}(\mathrm{g})$ (Figure 2A) and ${ }^{12} \mathrm{CH}_{\mathrm{x}}$-s with ${ }^{13} \mathrm{CH}_{\mathrm{x}}-\mathrm{S}\left(\mathrm{R}_{\mathrm{CH} x^{\prime}}^{e x}\right.$ Figure $\left.2 \mathrm{~B}\right)$ estimated from the SSITKA transient response curves recorded after $5 \mathrm{~h}$ in FTS at $230{ }^{\circ} \mathrm{C}$ (Figure 1, $\mathrm{x}$ vol $\%{ }^{12} \mathrm{CO} / 25 \mathrm{vol} \% \mathrm{H}_{2} / \mathrm{Ar} \rightarrow \mathrm{x} \mathrm{vol} \%{ }^{13} \mathrm{CO} / 25$ vol $\% \mathrm{H}_{2} / \mathrm{Kr} / \mathrm{Ar}, \mathrm{x}=3,5$, and 7). Estimation of these transient exchange rates was made after using Equations (3) and (4) (Section 4.2). The $R_{C O}^{e x}$ appears very fast, where, within the first $\sim 8 \mathrm{~s}$ after the switch from the non-isotopic ${ }^{12} \mathrm{CO} / \mathrm{H}_{2}$ to the equivalent isotopic ${ }^{13} \mathrm{CO} / \mathrm{H}_{2}$ gas mixture, all reversibly adsorbed CO-s was exchanged. It is also illustrated that this $R_{\mathrm{CO}}^{e x}$ rate of exchange increases with partial pressure of $\mathrm{CO}$ since it reflects the rate of adsorption of ${ }^{13} \mathrm{CO}$ on the surface after a Co-s surface site is freed by the desorption of ${ }^{12} \mathrm{CO}$-s. The rate of the latter process is proportional to the surface 
coverage of ${ }^{12} \mathrm{CO}$-s. If the ${ }^{12} \mathrm{CO}$-s at steady-state is in equilibrium with gas-phase ${ }^{12} \mathrm{CO}$, then the rate of desorption of ${ }^{12} \mathrm{CO}$-s must be equal to the rate of adsorption or exchange for ${ }^{13} \mathrm{CO}(\mathrm{g})$ during the SSITKA step-gas switch. Considering the shape profile of $R_{C O}^{e x}$ (Figure 2A), similar kinetics of ${ }^{12} \mathrm{CO}-\mathrm{s} /{ }^{13} \mathrm{CO}(\mathrm{g})$ exchange occurs independently of $\mathrm{P}_{\mathrm{CO}}$ (36-84 mbar). The surface coverage of CO-s $\left(\theta_{\mathrm{CO}}\right)$ in equilibrium with $\mathrm{P}_{\mathrm{CO}}$ increases with partial pressure of $\mathrm{CO}$ (area under the $\mathrm{R}_{\mathrm{CO}}$ vs. time response curve), as previously mentioned.
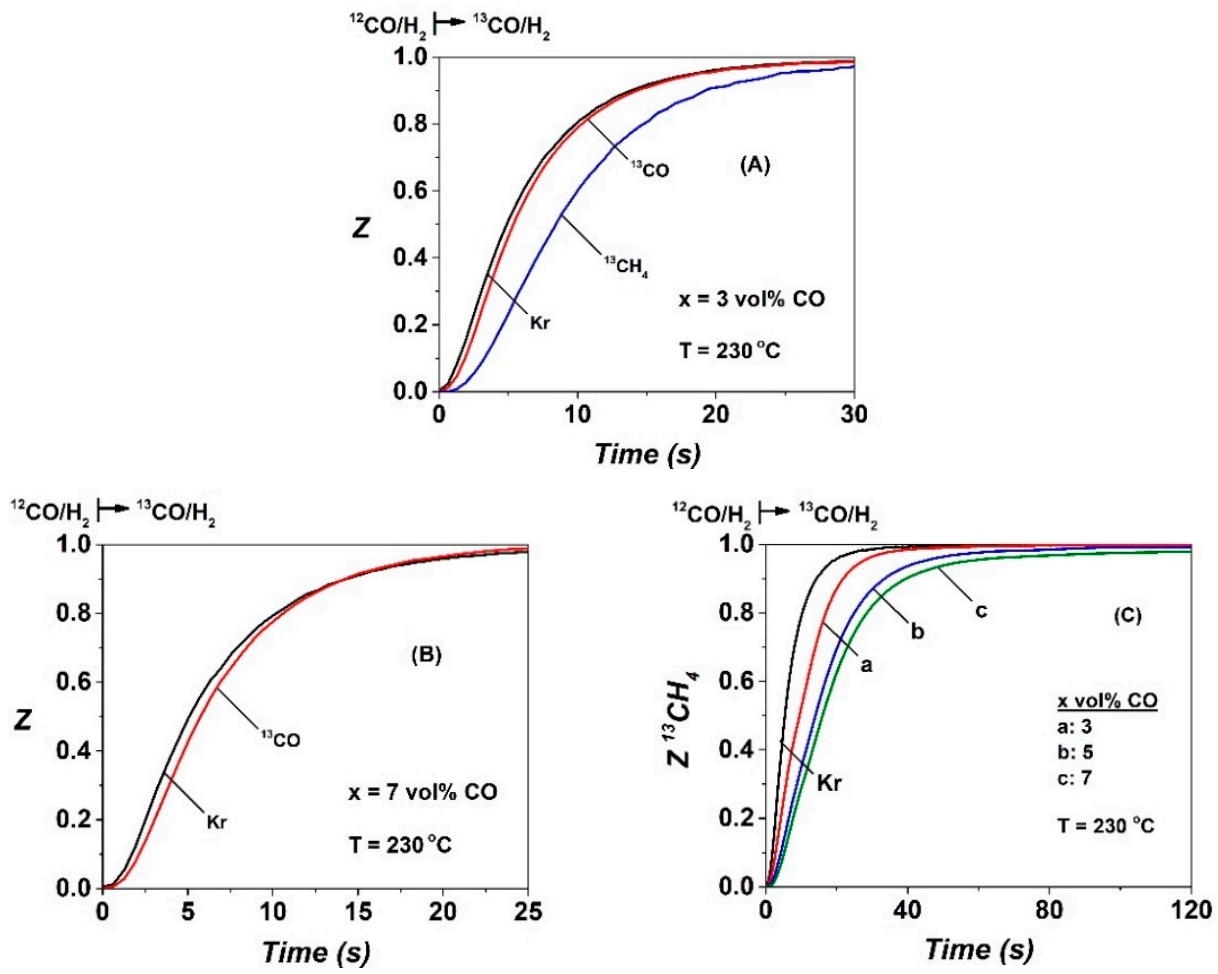

Figure 1. Normalized concentration $(\mathrm{Z})$ transient response curves of $(\mathrm{A}) \mathrm{Kr},{ }^{13} \mathrm{CO}$, and ${ }^{13} \mathrm{CH}_{4}$ obtained after the Steady State Isotopic Transient Kinetic Analysis (SSITKA) step-gas switch 3 vol\% CO/25 vol\% $\mathrm{H}_{2} / \mathrm{Ar}(5 \mathrm{~h}) \rightarrow 3 \mathrm{vol} \%{ }^{13} \mathrm{CO} / 25 \mathrm{vol} \% \mathrm{H}_{2} / 1$ vol $\% \mathrm{Kr} / \mathrm{Ar}(\mathrm{t}),(\mathbf{B}) \mathrm{Kr}$ and ${ }^{13} \mathrm{CO}$ obtained after the SSITKA switch with $7 \mathrm{vol} \% \mathrm{CO}$ in the feed gas composition, and (C) $\mathrm{Kr}$ and ${ }^{13} \mathrm{CH}_{4}$ obtained after the SSITKA switch to $x$ vol $\%{ }^{13} \mathrm{CO} / 25 \mathrm{vol} \% \mathrm{H}_{2} / 1 \mathrm{vol} \% \mathrm{Kr} / \mathrm{Ar}(\mathrm{t})$ at $230{ }^{\circ} \mathrm{C}$ over the $20 \mathrm{wt} \% \mathrm{Co} / \gamma-\mathrm{Al}_{2} \mathrm{O}_{3}$ catalyst, $\mathrm{x}=3$ (a), 5 (b), and 7 (c).

Table 1. Important kinetic parameters obtained after SSITKA following $5 \mathrm{~h}$ in $\mathrm{CO} / \mathrm{H}_{2}$ reaction at $230{ }^{\circ} \mathrm{C}$ over the $20 \mathrm{wt} \% \mathrm{Co} / \gamma-\mathrm{Al}_{2} \mathrm{O}_{3}$ catalyst with various feed gas compositions ( $\mathrm{x} \mathrm{vol} \% \mathrm{CO} / 25 \mathrm{vol} \% \mathrm{H}_{2} / \mathrm{Ar}$; $\mathrm{x}=3,5$, and 7 ).

\begin{tabular}{|c|c|c|c|c|c|c|c|c|c|c|}
\hline $\mathrm{CO}$ & $\mathbf{N}_{\mathrm{CO}}$ & \multirow{2}{*}{$\theta_{\mathrm{CO}}$} & $\mathbf{N}_{\mathrm{CHx}}$ & \multirow{2}{*}{$\theta_{\mathrm{CHx}}$} & \multirow{2}{*}{$\begin{array}{c}\text { УCH4, s.s } \\
(\mathrm{ppm})\end{array}$} & $\mathrm{TOF}_{\text {chem }}$ & TOF $_{\text {ITK }}$ & \multirow{2}{*}{$\begin{array}{c}\tau_{\mathrm{CHx}} \\
\text { (s) }\end{array}$} & $\mathbf{k}_{\text {eff }}$ & \multirow{2}{*}{$\begin{array}{c}\mathrm{S}_{\mathrm{CH} 4} \\
(\%)\end{array}$} \\
\hline vol $\%$ & $\left(\mu \mathrm{mol} \mathrm{g}^{-1}\right)$ & & $\left(\mu \mathrm{mol} \mathrm{g}^{-1}\right)$ & & & $\left(\times 10^{3}, \mathrm{~s}^{-1}\right)$ & $\left(\times 10^{3}, \mathrm{~s}^{-1}\right)$ & & $\left(\times 10^{2}, s^{-1}\right)$ & \\
\hline 3 & 10.0 & 0.029 & 15.8 & 0.047 & 3870 & 9.7 & 127.7 & 4.8 & 20.8 & 60 \\
\hline 5 & 10.8 & 0.032 & 28.8 & 0.085 & 2690 & 7.4 & 61.5 & 12.0 & 8.3 & 38.5 \\
\hline 7 & 16.5 & 0.048 & 39.7 & 0.117 & 4380 & 7.3 & 44.2 & 16.0 & 6.3 & 35 \\
\hline
\end{tabular}

The $\mathrm{R}_{\mathrm{CHx}}\left(\mu \mathrm{mol} \mathrm{g} \mathrm{g}^{-1} \mathrm{~s}^{-1}\right)$ transient rate response curve depicted in Figure $2 \mathrm{~B}$ show a similar shape with increasing $\mathrm{P}_{\mathrm{CO}}$, where the rate maximum is shifted to higher reaction times and presents a longer tail until completion of $\mathrm{CH}_{\mathrm{x}}$-s exchange. By increasing the $\mathrm{CO}$ partial pressure $(\mathrm{x}=3,5$, and $7 \mathrm{vol} \%$ $\mathrm{CO}$ ) in the feed gas stream, the initial $\mathrm{R}_{\mathrm{CHx}}$ rate (during the very first few seconds of the transient) increases from $0.95 \mu \mathrm{mol} \mathrm{g}^{-1} \mathrm{~s}^{-1}$ to 1.23 and $1.35 \mu \mathrm{mol} \mathrm{g}^{-1} \mathrm{~s}^{-1}$, respectively, with the time required for complete exchange to occur at 50,120 and $170 \mathrm{~s}$, respectively. These features support the view of two kinds of $\mathrm{CH}_{\mathrm{x}}$-s species formed in the $\mathrm{CO} / \mathrm{H}_{2}$ reaction $\left(230^{\circ} \mathrm{C}, 5 \mathrm{~h}\right)$. One is hydrogenated to $\mathrm{CH}_{4}$ with a 
faster rate than a second one of a lower rate, where the latter is responsible for the appearance of a tail (Figure 2B). These features will be further discussed below.
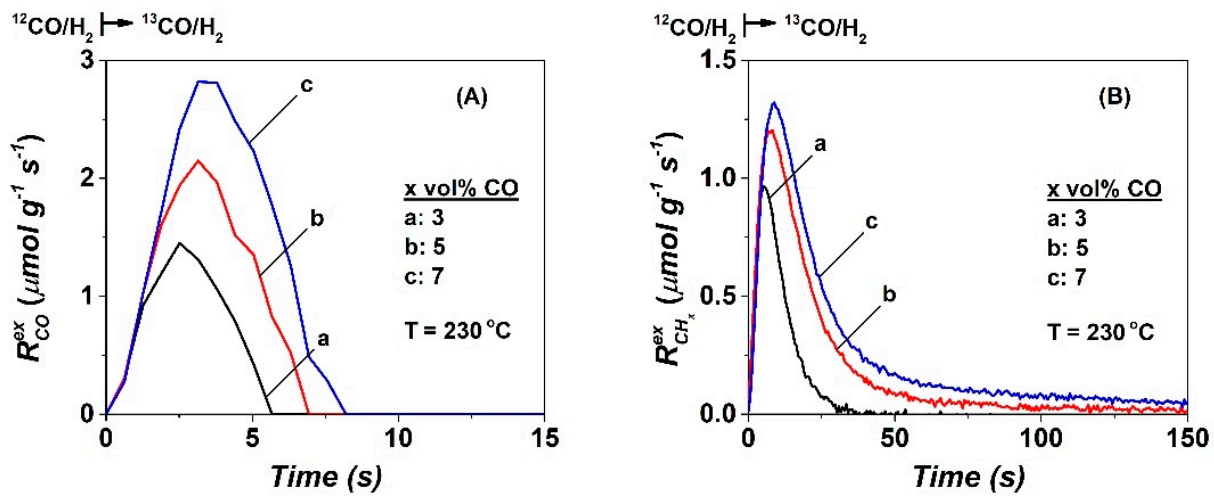

Figure 2. Transient rates ( $\mu \mathrm{mol} \mathrm{g} \mathrm{g}^{-1} \mathrm{~s}^{-1}$ ) of $(\mathbf{A}){ }^{12} \mathrm{CO}-\mathrm{s}$ exchange and $(\mathbf{B}){ }^{12} \mathrm{CH}_{\mathrm{x}}-\mathrm{s}$ exchange as a function of time estimated after the SSITKA step-gas switch $\mathrm{x}$ vol $\%{ }^{12} \mathrm{CO} / 25 \mathrm{vol} \% \mathrm{H}_{2} / \mathrm{Ar}(5 \mathrm{~h}) \rightarrow \mathrm{x}$ vol $\%{ }^{13} \mathrm{CO} / 25$ $\mathrm{vol} \% \mathrm{H}_{2} / 1 \mathrm{vol} \% \mathrm{Kr} / \mathrm{Ar}(\mathrm{t})$ at $230{ }^{\circ} \mathrm{C}$ performed on the $20 \mathrm{wt} \% \mathrm{Co} / \gamma-\mathrm{Al}_{2} \mathrm{O}_{3}$ catalyst, $\mathrm{x}=3$ (a), 5 (b) and 7 (c).

The mean lifetimes $\tau_{\mathrm{CO}}$ and $\tau_{\mathrm{CHx}}(\mathrm{s})$ of the adsorbed $\mathrm{CO}$-s and active $\mathrm{CH}_{\mathrm{x}}$-s intermediates, respectively, were estimated based on the experimental results shown in Figure 1 after using Equations (8) and (9) (Section 4.2). The obtained results are given in Table 1 and Figure $3 \mathrm{~A}$ as a function of the partial pressure of $\mathrm{CO}$. The mean residence time $\tau_{\mathrm{CO}}(\mathrm{s})$ is practically independent of $\mathrm{P}_{\mathrm{CO}}(0.35-0.5 \mathrm{~s})$, while that of $\tau_{\mathrm{CHx}}$ (s) largely increases with increasing $\mathrm{P}_{\mathrm{CO}}$ (Figure $3 \mathrm{~A}$ and Table 1 ). An increase by $\sim 3.3$ times is seen after increasing the $\mathrm{P}_{\mathrm{CO}}$ from 36 to 84 mbar (4.8 vs. $16 \mathrm{~s}$ ).
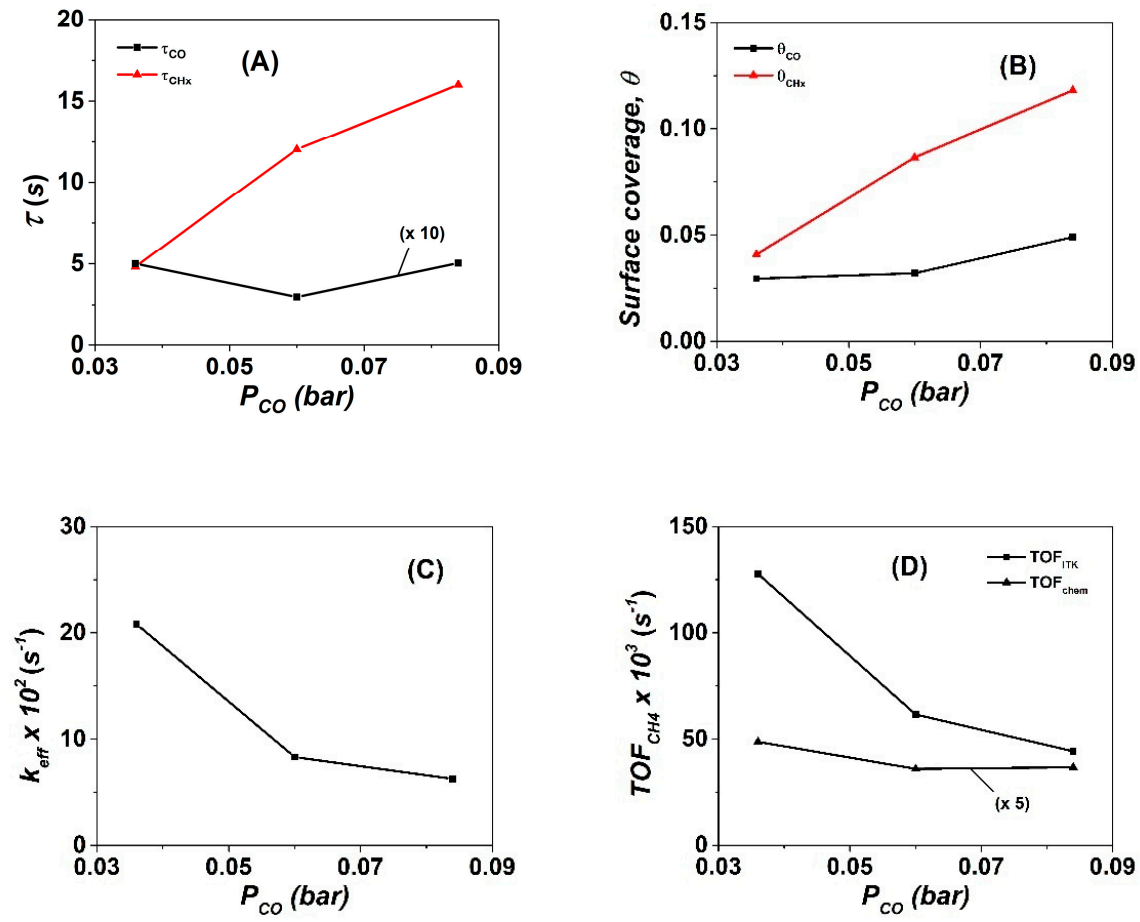

Figure 3. (A) Mean residence time of CO-s $\left(\tau_{\mathrm{CO}}, \mathrm{s}\right)$ and active $\mathrm{CH}_{\mathrm{x}}\left(\tau_{\mathrm{CHx}}, \mathrm{s}\right),(\mathbf{B})$ surface coverages of CO-s $\left(\theta_{\mathrm{CO}}\right)$ and active $\mathrm{CH}_{\mathrm{x}}\left(\theta_{\mathrm{CHx}}\right),(\mathbf{C})$ effective rate constant $\left(\mathrm{k}_{\mathrm{eff}}, \mathrm{s}^{-1}\right)$ of methane formation, and (D) intrinsic kinetic rates of methane formation in terms of $\mathrm{TOF}_{\mathrm{ITK}}$ and $\mathrm{TOF}_{\text {chem }}\left(\mathrm{s}^{-1}\right)$ as a function of CO partial pressure (bar) obtained after the SSITKA step-gas switch following $5 \mathrm{~h}$ in the $\mathrm{CO} / \mathrm{H}_{2}$ reaction over the $20 \mathrm{wt} \% \mathrm{Co} / \gamma-\mathrm{Al}_{2} \mathrm{O}_{3}$ catalyst. 
The concentration $\left(\mu \mathrm{mol} \mathrm{g}^{-1}\right)$ and surface coverage of adsorbed $\mathrm{CO}, \theta_{\mathrm{CO}}$, were found to increase by $10 \%$ to $65 \%$ with increasing CO partial pressure, ca. $\theta_{\mathrm{CO}}=0.029,0.032$, and 0.048 for 36,60 , and $84 \mathrm{mbar}$ $\mathrm{P}_{\mathrm{CO}}$ (Figure $3 \mathrm{~B}$ and Table 1$)$. A significantly larger increase is obtained for the concentration $\left(\mu \mathrm{mol} \mathrm{g}{ }^{-1}\right)$ and surface coverage of $\mathrm{CH}_{\mathrm{x}}$-s (Figure 3B), where $\theta_{\mathrm{CHx}}$ increases from 0.047 to 0.085 and 0.117 for 36 to 60 and 84 mbar CO partial pressure, respectively. An increase by a factor of 2.5 is obtained after increasing the $\mathrm{P}_{\mathrm{CO}}$ from 36 to 84 mbar. The latter values are in the range of those previously published over supported Co catalysts [8,39]. Carvalho et al. [45] reported that, for the methanation reaction at $250{ }^{\circ} \mathrm{C}$ over $20 \mathrm{wt} \% \mathrm{Co} / \mathrm{SiO}_{2}$ and $20 \mathrm{wt} \% \mathrm{Co}-0.1 \mathrm{wt} \% \mathrm{Pt} / \mathrm{SiO}_{2}$ catalysts, the mean lifetime of $\mathrm{CO}$-s and $\mathrm{CH}_{\mathrm{x}}$-s active intermediates decreased with an increasing $\mathrm{H}_{2} / \mathrm{CO}$ gas ratio due to the greater surface coverage of hydrogen, $\theta_{\mathrm{H}}$, and the lower surface coverage of CO-s, $\theta_{\mathrm{CO}}$. They reported that these changes with $\mathrm{H}_{2} / \mathrm{CO}$ gas ratio were responsible for the increased hydrogenation rate of $\mathrm{CH}_{\mathrm{x}}-\mathrm{s}$. The decrease of $\theta_{\mathrm{CO}}$ with an increasing $\mathrm{H}_{2} / \mathrm{CO}$ gas ratio was reported [46] to have a positive effect on the ratio of $\theta_{\mathrm{H}} / \theta_{*_{*}}$, where $\theta_{*_{\mathrm{H}}}$ represents the surface coverage of empty sites on the Co surface. This $\theta_{\mathrm{H}} / \theta_{*_{H}}$ parameter plays a crucial role in the FTS reaction discussed below.

The $\mathrm{k}_{\mathrm{eff}}\left(\mathrm{s}^{-1}\right)$ value of the methanation reaction was estimated based on Equation (12) (Section 4.2). This is plotted against the partial pressure of $\mathrm{CO}$ as depicted in Figure 3C. It is noted that $\mathrm{k}_{\text {eff }}=\mathrm{k}_{\mathrm{CHx}} \theta_{\mathrm{H}}$. A three-fold decrease in $\mathrm{k}_{\text {eff }}\left(\mathrm{s}^{-1}\right)$ is observed with increasing CO partial pressure, namely, $\mathrm{k}_{\text {eff }}=20.8$, 8.31 , and $6.26 \times 10^{-2} \mathrm{~s}^{-1}$, for 36, 60, and $84 \mathrm{mbar} \mathrm{CO}$, respectively (Figure 3C).

Based on the surface coverages of $\theta_{\mathrm{CO}}$ and $\theta_{\mathrm{CHx}}$, the $\tau_{\mathrm{CO}}$ and $\tau_{\mathrm{CHx}}$ values, the $\mathrm{TOF}_{\text {chem }}$ and $\mathrm{TOF}_{\text {ITK }}\left(\mathrm{s}^{-1}\right)$ of $\mathrm{CH}_{4}$ formation were estimated (see Equations (10) and (11), Section 4.2) and results are shown in Figure 3D. The $\mathrm{TOF}_{\text {chem }}\left(\mathrm{s}^{-1}\right)$ (estimated based on the total Co surface metal atoms) was found to slightly decrease with increasing $\mathrm{P}_{\mathrm{CO}}$, namely: $9.74,7.40$, and $7.34 \times 10^{-3} \mathrm{~s}^{-1}$, respectively, for 36,60 , and 84 mbar CO. However, in the case of $\operatorname{TOF}_{\text {ITK }}\left(\mathrm{s}^{-1}\right)$, which is estimated based on the total concentration of active $\mathrm{CH}_{\mathrm{x}}$-s and reversibly adsorbed $\mathrm{CO}-\mathrm{s}$, this was found to decrease by 2.1 and 2.9 times, respectively, in the case of 60 and 84 mbar CO compared to the case of $36 \mathrm{mbar} C O$ in the feed gas stream $\left(\operatorname{TOF}_{\text {ITK }}\left(\mathrm{s}^{-1}\right)=127.7,61.5\right.$, and $44.2 \times 10^{-3} \mathrm{~s}^{-1}$, respectively, Figure 3D). These differences in $\mathrm{TOF}_{\text {ITK }}\left(\mathrm{s}^{-1}\right)$ are attributed to the different concentration of active sites accommodating CO-s and $\mathrm{CH}_{\mathrm{x}}$-s that truly participate in the carbon-path of methanation reaction, which were both influenced by the partial pressure of $\mathrm{CO}$ (Figure $3 \mathrm{~B}$ ). The latter results are in good agreement with the work of Carvalho et al. [45] over the $\mathrm{Co} / \mathrm{SiO}_{2}$ and $\mathrm{CoPt} / \mathrm{SiO}_{2}$ catalysts, where, at higher hydrogen partial pressures (higher $\mathrm{H}_{2} / \mathrm{CO}$ ), an increased $\theta_{\mathrm{H}}$ favoured the rate of $\mathrm{CO}$ hydrogenation to methane. The $\operatorname{TOF}_{\text {ITK }}\left(\mathrm{s}^{-1}\right)$ was found to increase with an increasing $\mathrm{H}_{2} / \mathrm{CO}$ gas ratio. In fact, an increase by a factor of $\sim 1.6$ was reported for the $\mathrm{TOF}_{\text {ITK }}$ after an increase of $\mathrm{H}_{2} / \mathrm{CO}$ from 2 to 5 to be compared to the increase of $\sim 1.4$ in the present work $\left(\mathrm{CoPt} / \gamma-\mathrm{Al}_{2} \mathrm{O}_{3}\right.$, after increasing the $\mathrm{H}_{2} / \mathrm{CO}$ gas ratio from $\sim 3.6$ to 5.0 (Table $1, \mathrm{y}_{\mathrm{CO}}^{\mathrm{f}}=5$ and $7 \mathrm{vol} \%$ ).

Kinetic methane selectivity values $\mathrm{S}_{\mathrm{CH} 4}(\%)$ measured at $230^{\circ} \mathrm{C}$ and for the applied partial pressures of $\mathrm{H}_{2}$ and $\mathrm{CO}$ are also reported in Table 1 . It is clearly seen that $\mathrm{S}_{\mathrm{CH} 4}(\%)$ decreases substantially with increasing $\mathrm{P}_{\mathrm{CO}}$. In particular, the increase of $\mathrm{P}_{\mathrm{CO}}$ from $36 \mathrm{mbar}(3 \mathrm{vol} \%)$ to $60(5 \mathrm{vol} \%)$ and $84 \mathrm{mbar}$ $(7 \mathrm{vol} \%)$ results in the decrease of $\mathrm{CH}_{4}$-selectivity by a factor of 1.55 and 1.71 , respectively. Ma et al. [47] reported a very comprehensive kinetic study of methanation reaction over the $25 \mathrm{wt} \% \mathrm{Co} / \gamma-\mathrm{Al}_{2} \mathrm{O}_{3}$ catalyst at $220{ }^{\circ} \mathrm{C}$ and for a wide range of partial pressures of $\mathrm{H}_{2}$ and $\mathrm{CO}$. The authors derived a $\mathrm{CH}_{4}$-selectivity relationship as a function of $\mathrm{P}_{\mathrm{H} 2}, \mathrm{P}_{\mathrm{CO}}$, and $\mathrm{P}_{\mathrm{H} 2 \mathrm{O}}$ (see Reference [47], Equation (9)). We have applied the latter relationship to the present kinetic experimental data considering that $\mathrm{P}_{\mathrm{H} 2 \mathrm{O}}$ can be given by: $\mathrm{P}_{\mathrm{H} 2 \mathrm{O}}=\mathrm{y}_{\mathrm{H} 2 \mathrm{O}} \mathrm{P}_{\mathrm{T}}=\left(\mathrm{F}_{\mathrm{CO}, \mathrm{f}} \mathrm{X}_{\mathrm{CO}} / \mathrm{F}_{\mathrm{T}}\right) \mathrm{P}_{\mathrm{T}}$, where $\mathrm{P}_{\mathrm{T}}=1.2$ bar (total pressure), $\mathrm{F}_{\mathrm{CO}, \mathrm{f}}=\mathrm{CO}$ molar feed flow rate (mols $\mathrm{CO} / \mathrm{s})$, and $\mathrm{F}_{\mathrm{T}}=$ total feed molar flow rate $(\mathrm{mols} / \mathrm{s})$. It was found that $\mathrm{S}_{\mathrm{CH} 4}(\%)$ at the lowest $\mathrm{P}_{\mathrm{CO}}(36 \mathrm{mbar}, 3 \mathrm{vol} \% \mathrm{CO})$ decreases by a factor of 1.4 and 1.78 with increasing $\mathrm{P}_{\mathrm{CO}}$ to $60 \mathrm{mbar}(5 \mathrm{vol} \%)$ and $84 \mathrm{mbar}(7 \mathrm{vol} \%)$, respectively. These values agree very well with the measured experimental values given in Table 1 , considering the slightly different reaction $\mathrm{T}$ ( $230 \mathrm{vs}$. $220^{\circ} \mathrm{C}$ ) and Co mean particle size used in these studies. 


\subsection{Transient Isothermal and Temperature-Programmed Hydrogenation (TIH/TPH)}

Figure 4 presents the transient rates $\left(\mu \mathrm{mol} \mathrm{g}{ }^{-1} \mathrm{~s}^{-1}\right.$ ) of ${ }^{12} \mathrm{CH}_{4}$ and ${ }^{13} \mathrm{CH}_{4}$ obtained during hydrogenation of carbonaceous species formed after $5 \mathrm{~h}$ in the $\mathrm{CO} / \mathrm{H}_{2}$ reaction at $230{ }^{\circ} \mathrm{C}$, according to the following sequence of step-gas switches: $\mathrm{x} \%{ }^{12} \mathrm{CO} / 25 \% \mathrm{H}_{2} / \mathrm{Ar}\left(5 \mathrm{~h}, 230{ }^{\circ} \mathrm{C}\right) \rightarrow \mathrm{x} \%{ }^{13} \mathrm{CO} / 25 \%$ $\mathrm{H}_{2} / 1 \% \mathrm{Kr} / \mathrm{Ar}\left(230{ }^{\circ} \mathrm{C}, 7 \mathrm{~min}, \mathrm{SSITKA}\right) \rightarrow \mathrm{Ar}(3 \mathrm{~min}) \rightarrow 50 \% \mathrm{H}_{2} / \mathrm{Ar}(\mathrm{t}), \mathrm{TIH}\left(7 \mathrm{~min}, 230{ }^{\circ} \mathrm{C}\right)(\mathrm{see}$ Section 4.3). The transient response curves of ${ }^{12} \mathrm{CH}_{4}$ depicted in Figure $4 \mathrm{~A}$ are due to the hydrogenation of inactive (spectator) ${ }^{12} \mathrm{C}$-containing species (named $\mathrm{C}_{\beta}$ ) not participating in the formation of $\mathrm{CH}_{4}$ under steady-state FTS reaction conditions. It is seen that $\mathrm{P}_{\mathrm{CO}}$ in the feed gas stream influences both the shape of the transient rate and the amount of $C_{\beta}$. The former reflects the kinetics of hydrogenation of $C_{\beta}$, which is expected to depend on its reactivity $(k)$ and the rate-determining step (RDS) in the reaction path of hydrogenation $[48,49]$. Of interest is the long tail out for more than $100 \mathrm{~s}$ in the hydrogen stream, irrespective of the $\mathrm{CO}$ partial pressure used in the feed stream. This result is similar to the TIH of carbon formed after the $\mathrm{CO} / \mathrm{He}$ reaction at $250{ }^{\circ} \mathrm{C}$ on a $\mathrm{Rh} / \mathrm{MgO}$ catalyst [49].
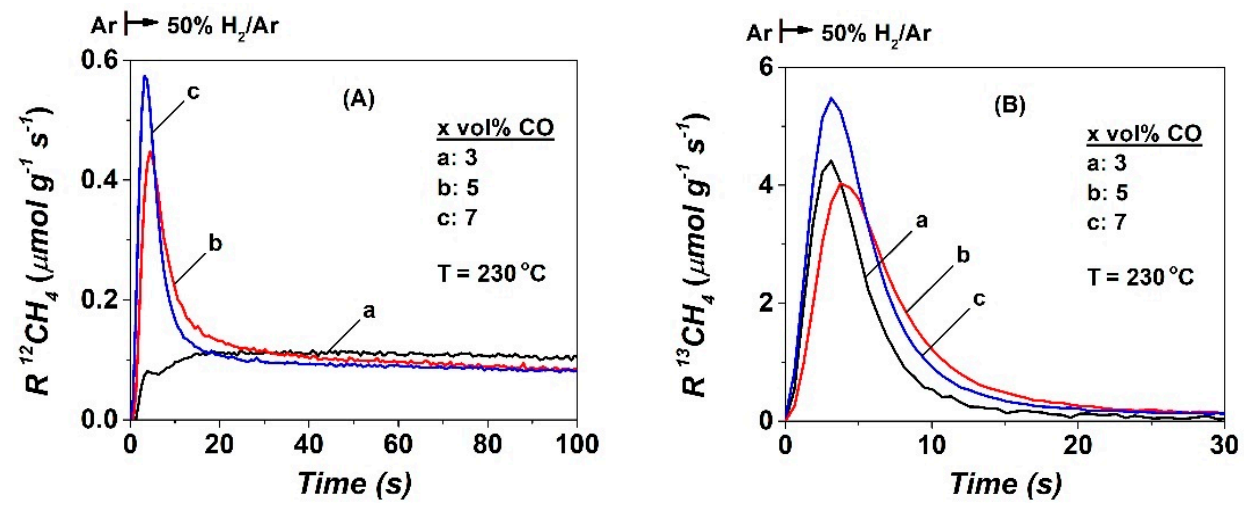

Figure 4. (A) Transient rates of ${ }^{12} \mathrm{CH}_{4}$ formation due to the isothermal hydrogenation (TIH) of ${ }^{12} \mathrm{C}$-containing species, and (B) transient rates of ${ }^{13} \mathrm{CH}_{4}$ formation due to the isothermal hydrogenation of ${ }^{13} \mathrm{C}$-containing species obtained during the last step of the sequence of step-gas switches conducted at $230{ }^{\circ} \mathrm{C}: \mathrm{x} \%{ }^{12} \mathrm{CO} / 25 \% \mathrm{H}_{2} / \mathrm{Ar}(5 \mathrm{~h}) \rightarrow \operatorname{SSITKA}(7 \mathrm{~min}) \rightarrow \operatorname{Ar}(3 \mathrm{~min}) \rightarrow 50 \% \mathrm{H}_{2} / \mathrm{Ar}(\mathrm{t}), \mathrm{TIH}, \mathrm{x}=3(\mathrm{a})$, 5 (b), and 7 (c).

The transient rate of ${ }^{13} \mathrm{CH}_{4}$ (Figure 4B) reflects the hydrogenation of ${ }^{13} \mathrm{C}$-containing reaction intermediates exchanged at $230{ }^{\circ} \mathrm{C}$ after the SSITKA switch. It decays much faster than that of ${ }^{12} \mathrm{CH}_{4}$ (Figure 4A), and its maximum is also higher than the corresponding one of ${ }^{12} \mathrm{CH}_{4}$ (Figure $4 \mathrm{~A}$ ). These features show that the ${ }^{12} \mathrm{C}$-containing and ${ }^{13} \mathrm{C}$-containing species are different in reactivity towards hydrogenation to methane. The very sharp transient response of ${ }^{13} \mathrm{CH}_{4}$ at $\mathrm{t}<5 \mathrm{~s}$ is associated with the hydrogenation of the small amount of active $\mathrm{CH}_{\mathrm{x}}-\mathrm{s}$ species $\left(\mathrm{C}_{\alpha}\right)$ formed in $\mathrm{CO} / \mathrm{H}_{2}(5 \mathrm{~h})$ and exchanged (labelled ${ }^{13} \mathrm{CH}_{\mathrm{x}}$-s) under the SSITKA switch. It can be clearly seen that there is a small decrease in the maximum rate of ${ }^{13} \mathrm{CH}_{4}$ formation by increasing the $\mathrm{CO}$ concentration in the feed gas stream from 3 to $5 \mathrm{vol} \%$ ( $4.4 \mathrm{vs}$. $4.0 \mu \mathrm{mol} \mathrm{g} \mathrm{s}^{-1}$, respectively), while a further increase to 7 vol $\%$ leads to an increase in the rate maximum by $\sim 25 \%\left(5.5 \mu \mathrm{mol} \mathrm{g}^{-1} \mathrm{~s}^{-1}\right)$. However, this appears practically at the same time, ca. 4-6 s. Part of the ${ }^{13} \mathrm{CH}_{4}$ transient response (Figure 4B) is due to the hydrogenation of CO-s formed in $\mathrm{CO} / \mathrm{H}_{2}(5 \mathrm{~h})$ and exchanged under the SSITKA switch (Figure 1A,B, and Figure 3B). The hydrogenation of ${ }^{13} \mathrm{CO}-\mathrm{s}$ lasts for $20 \mathrm{~s}$ in the case when $3 \mathrm{vol} \% \mathrm{CO}$ was used in the feed. However, in the case of 5 and $7 \mathrm{vol} \% \mathrm{CO}$, the hydrogenation takes longer $(\sim 40 \mathrm{~s})$. The amounts $(\mu \mathrm{mol} / \mathrm{g})$ and surface coverages (based on the exposed Co surface metal atoms) of the corresponding $\mathrm{C}_{\beta}\left({ }^{12} \mathrm{CH}_{4}\right.$ transient) and those of $\mathrm{C}_{\alpha}$ and $\mathrm{CO}-\mathrm{s}\left({ }^{13} \mathrm{CH}_{4}\right.$ transient) are provided in Table 2 . The $\theta\left({ }^{13} \mathrm{CH}_{4}\right)$ was found to be $0.08,0.12$, and 0.17 for the 3,5 , and $7 \mathrm{vol} \% \mathrm{CO}$ used in the feed gas stream, respectively. It is pointed out that the sum of the surface coverages of CO-s and $\mathrm{C}_{\alpha}$ estimated during SSITKA is in very good agreement with the TIH results $\left(\theta\left({ }^{13} \mathrm{CH}_{4}\right)\right.$, Figure $\left.4 \mathrm{~B}\right)$. The amount $\left(\mu \mathrm{mol} \mathrm{g}{ }^{-1}\right)$ of hydrogenated $\mathrm{C}_{\beta}$ species given in Table 2 is found to be approximately the same irrespective of the partial pressure 
of CO in the feed gas stream, namely: $34.3(\theta=0.10), 27.6(\theta=0.08)$, and $30.4(\theta=0.09) \mu \mathrm{mol} \mathrm{g}^{-1}$ for the 3,5 , and $7 \mathrm{vol} \% \mathrm{CO}$ in the feed.

Table 2. Amounts ( $\left.\mu \mathrm{mol} \mathrm{g}^{-1}\right)$ and surface coverages $(\theta)$ of carbonaceous species formed at $230{ }^{\circ} \mathrm{C}$ after $5 \mathrm{~h}$ in FTS reaction $\left(\mathrm{x} \% \mathrm{CO} / 25 \% \mathrm{H}_{2} / \mathrm{Ar}\right)$, and which are hydrogenated at $230{ }^{\circ} \mathrm{C}(\mathrm{TIH})$ and during $\mathrm{TPH}$ $\left(240-600{ }^{\circ} \mathrm{C}\right)$.

\begin{tabular}{|c|c|c|c|c|c|c|}
\hline \multirow{3}{*}{ vol $\%$ CO } & TIH & TIH & TIH & TIH & ТPH & TPH \\
\hline & $\mathrm{N}\left({ }^{12} \mathrm{CH}_{4}\right)$ or $\mathrm{C}_{\beta}$ & $\theta\left({ }^{12} \mathrm{CH}_{4}\right)$ & $\mathrm{N}\left({ }^{13} \mathrm{CH}_{4}\right)$ & $\theta\left({ }^{13} \mathrm{CH}_{4}\right)$ & $\mathrm{N}\left({ }^{12} \mathrm{CH}_{4}\right)$ or $\mathrm{C}_{\gamma}$ & $\theta\left({ }^{12} \mathrm{CH}_{4}\right)$ \\
\hline & $\left(\mu \mathrm{mol} \mathrm{g}{ }^{-1}\right)$ & & $\left(\mu \mathrm{mol} \mathrm{g}^{-1}\right)$ & & $\left(\mu \mathrm{mol} \mathrm{g}{ }^{-1}\right)$ & \\
\hline 3 & 34.3 & 0.10 & 27.6 & 0.08 & 128 & 0.38 \\
\hline 5 & 27.6 & 0.08 & 40.2 & 0.12 & 228 & 0.67 \\
\hline 7 & 30.4 & 0.09 & 56.3 & 0.17 & 252 & 0.74 \\
\hline
\end{tabular}

The ${ }^{12} \mathrm{CH}_{4}$ transient response curves obtained during temperature-programmed hydrogenation $(\mathrm{TPH})$, following $5 \mathrm{~h}$ in $\mathrm{CO} / \mathrm{H}_{2}$ reaction and $7 \mathrm{~min} \mathrm{TIH}$ at $230{ }^{\circ} \mathrm{C}$, are reported in Figure 5 for the three $\mathrm{CO}$ concentrations used in the feed gas stream $(3,5$, and $7 \mathrm{vol} \% \mathrm{CO})$. The several hydrogenation peaks and shoulders that appeared in these TPH traces are attributed to inactive carbonaceous species (named $\mathrm{C}_{\gamma}$ ) formed during the FTS reaction, and which could not be hydrogenated at $230{ }^{\circ} \mathrm{C}$, as opposed to the $\mathrm{C}_{\beta}$ hydrogenated to methane at $230^{\circ} \mathrm{C}(\mathrm{TIH}$, Figure $4 \mathrm{~A})$. As shown in Figure $5 \mathrm{~A}$, the amount of $\mathrm{C}_{\gamma}$ (Table 2) is influenced by the $\mathrm{CO}$ feed gas concentration, as opposed to the shape and $\mathrm{T}_{\max }\left({ }^{\circ} \mathrm{C}\right)$ of the ${ }^{12} \mathrm{CH}_{4}$ traces. Furthermore, the fraction of the various types of $\mathrm{C}_{\gamma}$ carbonaceous species was found not to be influenced by the CO concentration in the feed, according to the deconvolution of the TPH traces performed (Figure 5B), and these results are reported in Table S1 (ESI). By increasing the CO concentration in the feed gas stream from 3 to 5 and $7 \mathrm{vol} \%$, the amount of $\mathrm{CH}_{4}$ formed was found to increase, ca. 128,228 , and $252 \mu \mathrm{mol} \mathrm{g}^{-1}$, respectively. Additionally, the main peak maximum is ca. 290, 420 , and $520 \mathrm{ppm}$, respectively (Figure 5A).
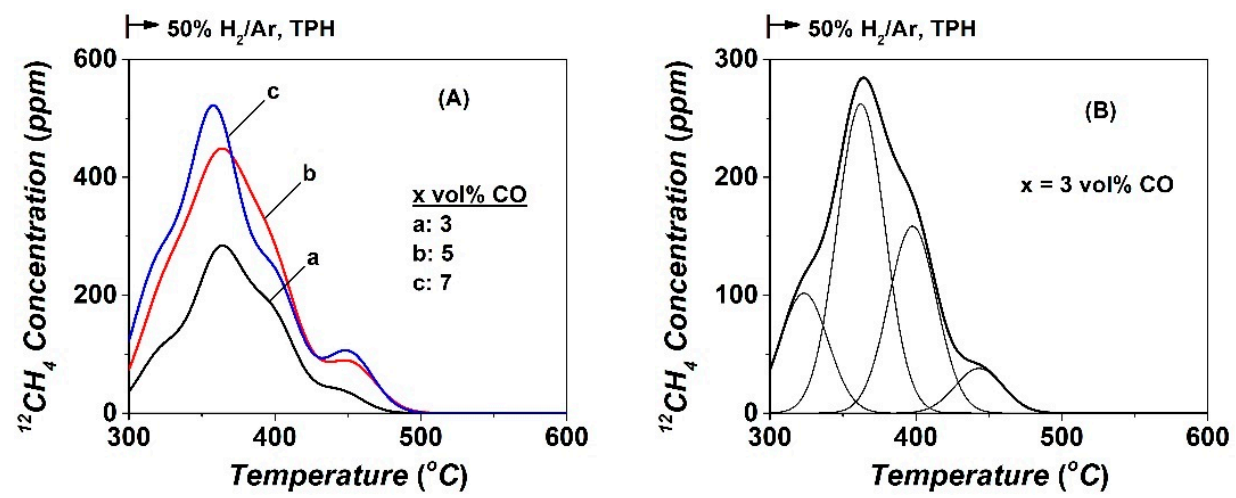

Figure 5. (A) ${ }^{12} \mathrm{CH}_{4}$-temperature programmed hydrogenation (TPH) traces of ${ }^{12} \mathrm{C}$-containing species formed after $5 \mathrm{~h}$ in $\mathrm{CO} / \mathrm{H}_{2}$ reaction at $230{ }^{\circ} \mathrm{C}$ over $\mathrm{Co} / \gamma-\mathrm{Al}_{2} \mathrm{O}_{3}$ using $\mathrm{x} \%{ }^{12} \mathrm{CO} / 25 \% \mathrm{H}_{2} / \mathrm{Ar}, \mathrm{x}=3$ (a), 5 (b), and 7 (c). (B) Deconvolution of the ${ }^{12} \mathrm{CH}_{4}-\mathrm{TPH}$ trace obtained following the $\mathrm{CO} / \mathrm{H}_{2}$ reaction with $3 \mathrm{vol} \% \mathrm{CO}$ in the feed.

\subsection{Operando DRIFTS—Transient Isothermal Hydrogenation (TIH) of CO}

Operando DRIFTS-Mass spectrometry experiments were conducted in the DRIFTS cell (PFR performance) in which the outlet was connected to a mass spectrometer [19]. After $2 \mathrm{~h}$ of methanation reaction at $200{ }^{\circ} \mathrm{C}\left(5 \mathrm{vol} \% \mathrm{CO} / 25 \mathrm{vol} \% \mathrm{H}_{2} / \mathrm{Ar}\right)$, the infra-red (IR) cell was purged with $\mathrm{Ar}$ for $3 \mathrm{~min}$, which was followed by a step-gas switch to $50 \mathrm{vol} \% \mathrm{H}_{2} / \mathrm{Ar}$ in order to study the transient kinetics of hydrogenation of each kind of adsorbed CO-s. Figure 6A shows the DRIFTS spectrum in the CO region $\left(1800-2250 \mathrm{~cm}^{-1}\right)$ and its deconvolution into five IR bands, following the deconvolution methodology previously described by us [19]. The IR bands marked (1) and (2) are due to the R and Q branches of 
gas-phase CO. The IR bands marked as (3) and (4) centered at 2015 and $1980 \mathrm{~cm}^{-1}$, respectively, are due to the presence of two linear-type reversibly chemisorbed CO-s. The third IR band centered at $1905 \mathrm{~cm}^{-1}$ is due to a bridged-type reversibly adsorbed CO-s [50-54]. At least one of these CO-s should be considered a precursor for methanation and higher HCs formation on the Co surface. The DRIFTS spectrum of Figure $6 \mathrm{~A}$ is in agreement with our previous results $\left(5 \mathrm{vol} \% \mathrm{CO}, \mathrm{H}_{2} / \mathrm{CO}=2\right)$ and others reported for different $\mathrm{H}_{2} / \mathrm{CO}$ gas ratios [19,50-54].
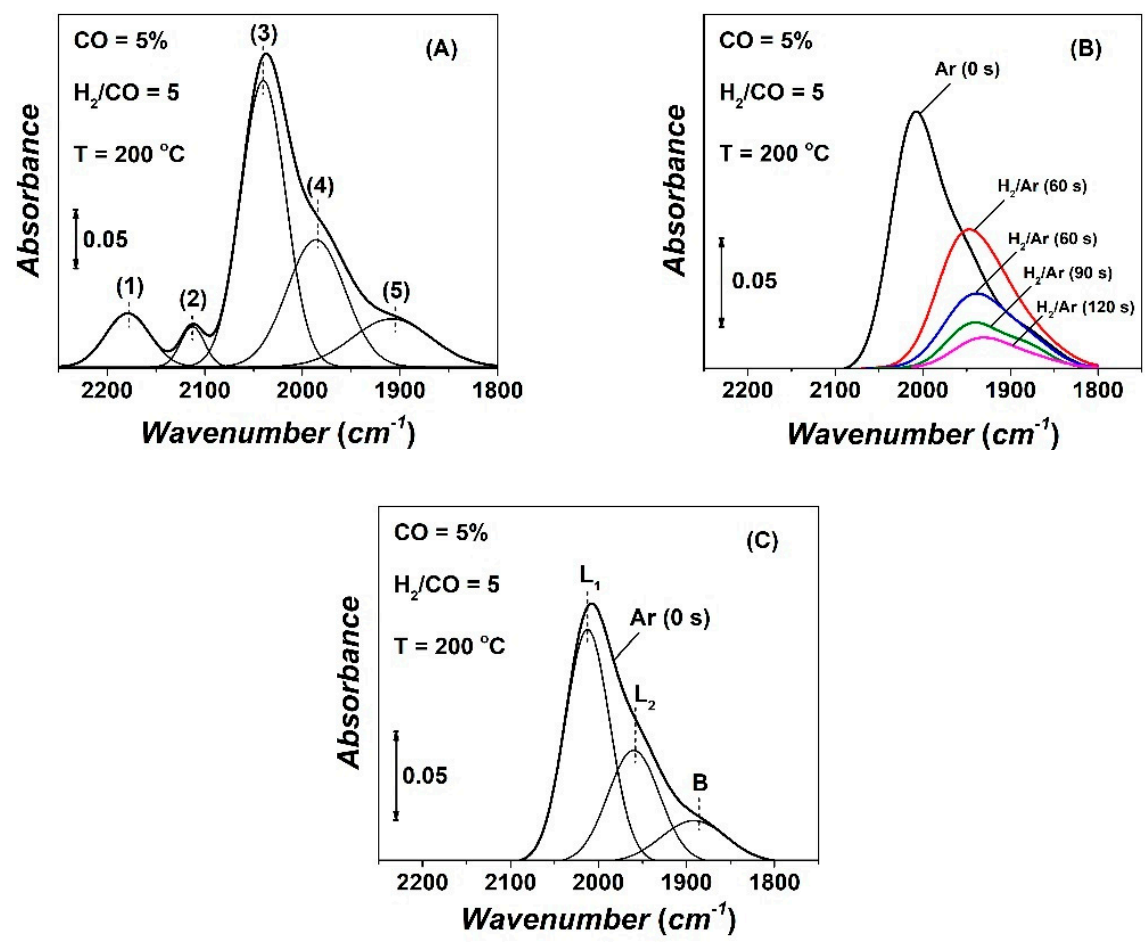

Figure 6. (A) DRIFTS spectrum in the CO region recorded in $5 \mathrm{vol} \% \mathrm{CO} / 25 \mathrm{vol} \% \mathrm{H}_{2} / \mathrm{Ar}\left(200{ }^{\circ} \mathrm{C}, 2 \mathrm{~h}\right)$ and its deconvolution. (B) DRIFTS spectra of adsorbed CO recorded in $50 \mathrm{vol} \% \mathrm{H}_{2} / \mathrm{Ar}(\mathrm{t})$ following $\mathrm{CO} / \mathrm{H}_{2}(2 \mathrm{~h})$ reaction at $200{ }^{\circ} \mathrm{C}$ and 3-min Ar purge $(\mathrm{t}=0)$. $(\mathbf{C})$ Deconvolution of the spectrum recorded in $\mathrm{Ar}(\mathrm{t}=0)$ before the step-gas switch to $50 \mathrm{vol}_{\mathrm{o}} \mathrm{H}_{2} / \mathrm{Ar}(\mathrm{t})$.

The DRIFTS spectrum recorded after the 3-min Ar purge is shown in Figure $6 \mathrm{~B}(\mathrm{Ar}, \mathrm{t}=0 \mathrm{~s}$ ) and its deconvolution into two kinds of linear CO-s $\left(\mathrm{L}_{1}, \mathrm{~L}_{2}\right)$ and one bridged-type CO-s $(\mathrm{B})$ is depicted in Figure $6 \mathrm{C}$. Upon the step-gas switch $\mathrm{Ar} \rightarrow 50 \mathrm{vol} \% \mathrm{H}_{2} / \mathrm{Ar}(\mathrm{t})$, the surface coverage of adsorbed CO-s (sum of $\mathrm{L}_{1}, \mathrm{~L}_{2}$, and $\mathrm{B}$ ) progressively decreases with time in hydrogen stream, and the maximum of the IR band shifts slightly to lower wavenumbers (Figure 6B). The latter is attributed to the effect of surface coverage of CO-s on its binding strength with the cobalt surface (lateral repulsive interactions between adjacent adsorbed CO-s). Thus, the bond energy between $\mathrm{C}$ and $\mathrm{O}$ within the adsorbed CO-s decreases, and, thereby, lowers the vibrational frequency as observed.

DRIFTS-TIH deconvoluted spectra with time of hydrogenation of the two linear-type $\left(\mathrm{L}_{1}, \mathrm{~L}_{2}\right)$ adsorbed CO-s species were further analysed by applying the microkinetic modelling described in detail [19]. Due to the small integral band area of the third bridged-type (B) adsorbed CO-s, no further analysis was attempted. Figure 7A,B show DRIFTS spectra of the evolution of the IR bands of $\mathrm{L}_{1}$ and $\mathrm{L}_{2}$ linear-type adsorbed CO-s with time in hydrogen gas stream, after following the same deconvolution procedure shown in Figure 6C (deconvolution in Ar gas stream). Both $\mathrm{L}_{1}$ and $\mathrm{L}_{2}$ adsorbed CO-s formed after $2 \mathrm{~h}$ in the $\mathrm{CO} / \mathrm{H}_{2}$ reaction at $200{ }^{\circ} \mathrm{C}$ were hydrogenated towards methane within the first $3 \mathrm{~min}$ in $50 \mathrm{vol} \% \mathrm{H}_{2} /$ Ar. Figure $7 \mathrm{C}$ plots the integral band intensity $\left(\mathrm{Abs} \mathrm{cm}^{-1}\right)$ of the $\mathrm{L}_{1}$ and $\mathrm{L}_{2}$ as a function of time in $50 \% \mathrm{H}_{2} / \mathrm{Ar}$ gas treatment. Assuming the same extinction coefficient for the two linear-type CO-s species, it is seen that the relative population of the two CO-s is $\mathrm{L}_{1}: \mathrm{L}_{2} \sim 65: 35 \%$. The integral 
bands of $\mathrm{L}_{1}$ and $\mathrm{L}_{2}$ follow a very similar decay with time in hydrogenation, which suggests similar kinetics of hydrogenation. This is confirmed by the following kinetic analysis.
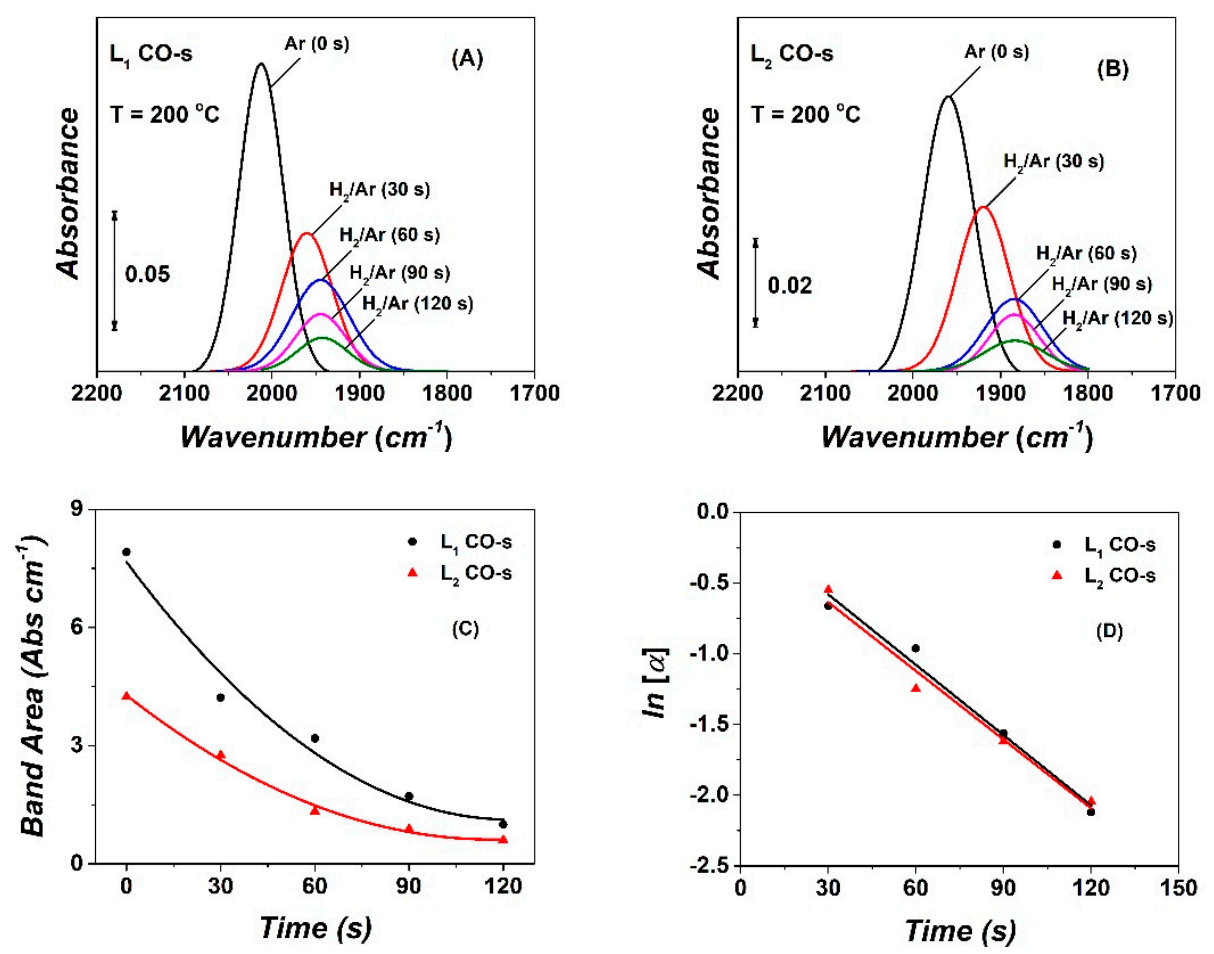

Figure 7. DRIFTS spectra of the $\mathrm{L}_{1}$ adsorbed CO-s (A) and $\mathrm{L}_{2}$ adsorbed CO-s (B) formed after $2 \mathrm{~h}$ in $\mathrm{CO} / \mathrm{H}_{2}$ reaction at $200{ }^{\circ} \mathrm{C}$ and recorded after 3-min Ar purge (IR band marked $\mathrm{Ar}(0 \mathrm{~s})$ ) and during the $50 \mathrm{vol} \% \mathrm{H}_{2} /$ Ar gas treatment (t), following Ar purge. (C) Evolution of integral band intensity with time in $50 \mathrm{vol} \% \mathrm{H}_{2} /$ Ar gas treatment. (D) Plot of $\ln [\alpha]$ vs. time (s) in $\mathrm{H}_{2} / \mathrm{Ar}$ for the $\mathrm{L}_{1}$ and $\mathrm{L}_{2}$ adsorbed CO-s species.

The transient kinetics of hydrogenation of CO-s was modelled via the $\mathrm{H}$-assisted $\mathrm{CO}$ dissociation mechanism [55-57], where the formation of hydroxymethylene species ( $\mathrm{HCOH}-\mathrm{s})$ from the sequential hydrogenation of CO-s was considered as the rate-determined step (RDS) [19]. Based on this kinetic analysis, an apparent rate constant $\left(\mathrm{k}_{\mathrm{eff}}, \mathrm{s}^{-1}\right)$ associated with this RDS was derived using Equation (2), where $k_{\text {eff }}$ is the product of the intrinsic rate constant $k$ times $\theta_{H}\left(k_{\text {eff }}=k \theta_{H}\right)$.

$$
\ln [a]=-k_{e f f} t ; a=\frac{A_{\mathrm{CO}}(t)}{A_{\mathrm{CO}}(t=0)}
$$

In Equation (2), $\alpha$ is equal to the ratio of the integral IR band intensity for each individual linear-type adsorbed CO-s at a given time, $\mathrm{t}$, in $\mathrm{H}_{2} / \mathrm{Ar}$ to the integral IR band intensity recorded at $\mathrm{t}=0$ (after the 3-min Ar purge before the $\mathrm{H}_{2} / \mathrm{Ar}$ step-gas switch was made).

Figure 7D presents linear plots of $\ln [\alpha]$ versus time in $\mathrm{H}_{2} / \mathrm{Ar}$ for the two $\left(\mathrm{L}_{1}, \mathrm{~L}_{2}\right)$ linear adsorbed CO-s species. Based on Equation (2), the slope of the linear $\ln [\alpha]$ vs. time plot provides the apparent rate constant $\left(\mathrm{k}_{\text {eff }}\right)$ of each of the two linear adsorbed CO-s. It is shown that the $\mathrm{L}_{1}$ and $\mathrm{L}_{2}$ adsorbed CO-s exhibit very similar reactivities ( $\mathrm{k}_{\text {eff_L1 }} / \mathrm{k}_{\text {eff_L2 }} \sim 1, \mathrm{k}_{\text {eff_L1 }}=0.016 \mathrm{~s}^{-1}$ ) toward hydrogenation to $\mathrm{CH}_{4}$. Since $\mathrm{k}_{\text {eff }}=\mathrm{k} \theta_{\mathrm{H}}$, the $\mathrm{L}_{1}$ and $\mathrm{L}_{2}$ linear-type CO-s have very similar intrinsic reactivities $\left(\mathrm{k}_{\mathrm{L} 1} \sim \mathrm{k}_{\mathrm{L} 2}\right)$. The $\mathrm{k}_{\text {eff }}$ value estimated is smaller than the one reported by us on the same $\mathrm{Co} / \gamma-\mathrm{Al}_{2} \mathrm{O}_{3}$ catalyst at $230{ }^{\circ} \mathrm{C}$ and for $\mathrm{H}_{2} / \mathrm{CO}=2\left(5 \% \mathrm{CO}, 10 \% \mathrm{H}_{2}\right)$. More precisely, $\mathrm{k}_{\text {eff_L1 }}=0.021$ and $\mathrm{k}_{\text {eff_L2 }}=0.027 \mathrm{~s}^{-1}$ with $\mathrm{k}_{\mathrm{L} 1} / \mathrm{k}_{\mathrm{L} 2}$ to be $0.78\left(230^{\circ} \mathrm{C}\right)$. Assuming that the pre-exponential factors are the same for the two rate constants, then the $\mathrm{k}_{\mathrm{L} 1} / \mathrm{k}_{\mathrm{L} 2}$ ratio takes the value of 0.76 at $200{ }^{\circ} \mathrm{C}$. Furthermore, the difference in the activation energies $\left(E_{1}-E_{2}, \mathrm{kcal} / \mathrm{mol}\right)$ of hydrogenation of these two linear-type $\mathrm{CO}$ species was 
estimated to be $\sim 0.3 \mathrm{kcal} \mathrm{mol}^{-1}$. The increase in the hydrogen partial pressure from 0.12 to $0.3 \mathrm{bar}$ (10 to $25 \mathrm{vol} \% \mathrm{H}_{2}, \mathrm{P}=1.2$ bar) has a very small influence on the intrinsic rate constant of CO-s hydrogenation via the $\mathrm{H}$-assisted $\mathrm{CO}$ dissociation mechanism (RDS: $\mathrm{HCO}-\mathrm{s}+\mathrm{H}-\mathrm{s} \rightarrow \mathrm{HCOH}-\mathrm{s}+\mathrm{s}$ ).

The transient evolution of $\mathrm{CH}_{4}$ formation during the DRIFTS-TIH experiment was recorded by online mass spectroscopy (operando methodology). This is depicted in Figure 8. At the same time, the gas-phase $\mathrm{CO}$ response was measured and compared to that of the $\mathrm{Kr}$ tracer, as shown in Figure 8. Based on the $\mathrm{Kr}$ and CO response curves, it is illustrated that desorption of $\mathrm{CO}$ during the $50 \% \mathrm{H}_{2} / \mathrm{Ar}$ gas treatment of the catalyst sample was negligible. The $\mathrm{CH}_{4}$ transient response (Figure 8) presents two rate peak maxima. The first one, which appeared at $\sim 8 \mathrm{~s}$, is largely due to the CO-s and active $\mathrm{CH}_{\mathrm{x}}$-s formed after $2 \mathrm{~h}$ of $\mathrm{CO} / \mathrm{H}_{2}$ reaction at $200{ }^{\circ} \mathrm{C}$, whereas the second peak centered at $\sim 40 \mathrm{~s}$ is largely due to the $\mathrm{C}_{\beta}$ species presented and discussed above (Section 2.3, Figure $4 \mathrm{~A}$ ). Integration of this transient response of $\mathrm{CH}_{4}$ provides the total amount ( $\mu \mathrm{mol} / \mathrm{g}$ or $\theta$ ) of CO-s, and active $\mathrm{CH}_{\mathrm{x}}-\mathrm{s}$ $\left(\mathrm{C}_{\alpha}\right)$ and $\mathrm{C}_{\beta}$ species formed after $2 \mathrm{~h}$ in $\mathrm{CO} / \mathrm{H}_{2}$ reaction. This amount was found to be $31.1 \mu \mathrm{mol} / \mathrm{g}$ $(\theta=0.09)$, as opposed to the value of $\theta=0.20$ obtained at $230{ }^{\circ} \mathrm{C}$ after $5 \mathrm{~h}$ in $\mathrm{CO} / \mathrm{H}_{2}$ (Table 2). It is reasonable to suggest that, since $\theta_{\mathrm{CO}}$ decreases with increasing rection $\mathrm{T}$, and $\theta_{\mathrm{CHx}}$ decreases with time-on-stream [11,21], then inactive $C_{\beta}$ appears to grow with an increasing reaction temperature from 200 to $230^{\circ} \mathrm{C}$.

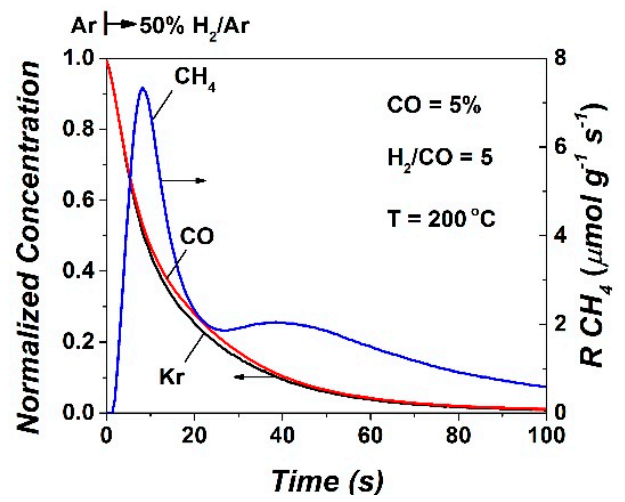

Figure 8. Normalized concentration of $\mathrm{Kr}$ (tracer) and $\mathrm{CO}$, and transient rate of $\mathrm{CH}_{4}$ formation ( $\mu$ mol $\mathrm{g}^{-1} \mathrm{~s}^{-1}$ ) obtained during the operando DRIFTS-MS transient isothermal hydrogenation (TIH) conducted at $200{ }^{\circ} \mathrm{C}$ over the $\mathrm{Co} / \gamma-\mathrm{Al}_{2} \mathrm{O}_{3}$ catalyst.

\section{Discussion}

\subsection{Influence of CO Partial Pressure on Intrinsic Kinetic Parameters of Methanation Reaction}

The increase of CO partial pressure from 36 to 84 mbar ( $3-7 \mathrm{vol} \% \mathrm{CO}, \mathrm{P}=1.2 \mathrm{bar}$ ), while keeping the $\mathrm{H}_{2}$ partial pressure constant at $300 \mathrm{mbar}(25 \mathrm{vol} \%)$, led to significant variations in several intrinsic kinetic parameters of the methanation reaction conducted at $230{ }^{\circ} \mathrm{C}$ and after $5 \mathrm{~h}$ over the $20 \mathrm{wt} \%$ $\mathrm{Co}-0.05 \mathrm{wt} \% \mathrm{Pt} / \gamma-\mathrm{Al}_{2} \mathrm{O}_{3}$ commercially relevant catalyst. The $\theta_{\mathrm{CO}}$ was found to be small, ca. 0.029 , 0.032 , and 0.049 for 36,60 , and 84 mbar, respectively, but with an increasing trend as the CO partial pressure increases and the $\mathrm{H}_{2} / \mathrm{CO}$ gas ratio decreases. An increase of $\theta_{\mathrm{CO}}$ by a factor of $\sim 1.68$ was obtained as the $\mathrm{CO}$ partial pressure increases from 36 to $84 \mathrm{mbar}$. The latter result agrees with the characteristic features of Langmuir isotherm and the fast ${ }^{12} \mathrm{CO}-\mathrm{s} /{ }^{13} \mathrm{CO}(\mathrm{g})$ exchange, which was revealed under SSITKA (see Figure $1 \mathrm{~A}, \mathrm{~B}$, and Figure $2 \mathrm{~A}$ ). The increase of $\theta_{\mathrm{CO}}$ with $\mathrm{P}_{\mathrm{CO}}$ finds agreement with the SSITKA work conducted by Chen et al. [18] over the $17.1 \mathrm{wt} \% \mathrm{Co}-0.04 \mathrm{wt} \% \mathrm{Pt} / \mathrm{SiO}_{2}$ catalyst. However, the reaction conditions of $\mathrm{T}=260^{\circ} \mathrm{C}$ and $\mathrm{P}_{\mathrm{H} 2}=0.45 \mathrm{bar}\left(\mathrm{P}_{\mathrm{CO}}\right.$ in the 15-90 mbar range) are different than in the present work $\left(230^{\circ} \mathrm{C}, \mathrm{P}_{\mathrm{H} 2}=0.3 \mathrm{bar}\right)$. The authors reported that $\theta_{\mathrm{CO}}$ increased from $\sim 0.18$ to $\sim 0.30$ in the examined $\mathrm{P}_{\mathrm{CO}}$ range. The differences in $\theta_{\mathrm{CO}}$ between that work [18] and the present one must be seen as the result of the influence of several reaction parameters on $\theta_{\mathrm{CO}}$, which were not the same. For example, the reaction $\mathrm{T}$, the time-on-stream $(5 \mathrm{~h}$ in the present work vs. $16 \mathrm{~h}$ in 
Reference [18]), the $\mathrm{H}_{2}$ partial pressure, and the Co mean particle size (10 $\mathrm{nm}$ in the present work vs. $15 \mathrm{~nm}$ in Reference [18]).

The effect of La-promotion of $\mathrm{Co} / \gamma-\mathrm{Al}_{2} \mathrm{O}_{3}$ catalysts toward methanation was investigated by Vada et al. [58] using the SSITKA technique at similar FTS reaction conditions ( $\mathrm{P}_{\mathrm{CO}}=0.036$ bar, $\mathrm{H}_{2} / \mathrm{CO}=10, \mathrm{~T}=220^{\circ} \mathrm{C}$ ) to those used in this work. They found similar surface coverages of $\theta_{\mathrm{CO}}=0.11$ and $\theta_{\mathrm{CHx}}=0.05$ as in the present work (Figure 3B). Yang et al. [59] in their SSITKA work on $\mathrm{Co} / \gamma-\mathrm{Al}_{2} \mathrm{O}_{3}$ using a $\mathrm{CO}$ partial pressure of $\mathrm{P}_{\mathrm{CO}}=55 \mathrm{mbar}, \mathrm{H}_{2} / \mathrm{CO}=10, \mathrm{~T}=210{ }^{\circ} \mathrm{C}$ and $\mathrm{P}_{\mathrm{T}}=1.85$ bar, and, after $5 \mathrm{~h}$ on FTS reaction stream, they reported a similar $\theta_{\mathrm{CHx}}$ value but larger $\theta_{\mathrm{CO}} \sim 0.3$. Thus, a larger $\mathrm{P}_{\mathrm{H} 2}$ ( 0.55 vs. 0.3 bar in the present work) and lower $\mathrm{T}\left(210 \mathrm{vs.} 230{ }^{\circ} \mathrm{C}\right.$ in the present work) led to larger $\theta_{\mathrm{CO}}$ values. In the case of $\mathrm{TOF}_{\text {chem, }}$ a value of $\sim 12.5 \times 10^{-3}\left(\mathrm{~s}^{-1}\right)$ was reported [59] and compared to the present value of $7.4 \times 10^{-3}\left(\mathrm{~s}^{-1}\right)$ for very similar $\mathrm{P}_{\mathrm{CO}}$ (55-60 mbar) but larger $\mathrm{P}_{\mathrm{H} 2}(0.55 \mathrm{vs}$. 0.3 bar in the present work). A $k_{\text {eff }}\left(\mathrm{CH}_{\mathrm{x}}\right)$ value of $\sim 0.1 \mathrm{~s}^{-1}$ was reported [59] compared to the value of $0.08 \mathrm{~s}^{-1}$ (Table 1) for the previously mentioned comparative experimental conditions.

Carvalho et al. [11,45] in their SSITKA works conducted at $250^{\circ} \mathrm{C}$ over Co-based catalysts reported that $\theta_{\mathrm{CO}}$ decreases and $\theta_{\mathrm{CHx}}$ increases with an increasing $\mathrm{H}_{2} / \mathrm{CO}$ gas ratio. The authors claimed that higher $\theta_{\mathrm{CHx}}$ could be linked to larger hydrogenation rates for higher hydrocarbons, which is in agreement with the decrease of $\mathrm{S}_{\mathrm{CH} 4}$ and increase of $\mathrm{S}_{\mathrm{C} 5+}$ [45]. These results are similar to those reported by Pena et al. [60] and those in the present work (Table 1), where, after increasing the CO partial pressure, an increase of $\theta_{\mathrm{CHx}}$ and a concomitant decrease in $\mathrm{S}_{\mathrm{CH} 4}$ are obtained. In addition, Keyvanloo et al. [33] reported that, by increasing the $\mathrm{CO}$ partial pressure, while keeping the $\mathrm{H}_{2}$ partial pressure constant, the $\mathrm{S}_{\mathrm{CH} 4}$ decreases. This result is similar to our findings, where the $\mathrm{S}_{\mathrm{CH} 4}$ (\%) behaviour with $\mathrm{P}_{\mathrm{CO}}$ and $\mathrm{P}_{\mathrm{H} 2}$ was presented and discussed in Section 2.2 in relation to kinetic modelling studies [47] conducted on the $\mathrm{Co} / \gamma-\mathrm{Al}_{2} \mathrm{O}_{3}$. In the present work, it was found that, after increasing the $\mathrm{H}_{2} / \mathrm{CO}$ gas ratio (decrease of $\mathrm{CO}$ partial pressure), the ratio of $\theta_{\mathrm{CO}} / \theta_{\mathrm{CHx}}$ grows toward unity. This result agrees with that found by Carvalho et al. [45], where, for $\mathrm{H}_{2} / \mathrm{CO}=2, \theta_{\mathrm{CO}}$ was higher than $\theta_{\mathrm{CHx}}$, whereas, for $\mathrm{H}_{2} / \mathrm{CO}=5, \theta_{\mathrm{CHx}}$ was higher than $\theta_{\mathrm{CO}}$. This trend of $\theta_{\mathrm{CO}} / \theta_{\mathrm{CHx}}$ with the $\mathrm{H}_{2} / \mathrm{CO}$ gas ratio is attributed to the competitive $\mathrm{H}_{2}$ and $\mathrm{CO}$ chemisorption where, after increasing the hydrogen partial pressure in a given range, $\theta_{\mathrm{H}}$ increases against $\theta_{\mathrm{CO}}$, which results in increasing rates for $-\mathrm{CH}_{\mathrm{x}}$ coupling and further hydrogenation to higher hydrocarbons (lowering the $\mathrm{S}_{\mathrm{CH} 4}$ ).

The mean residence time of active $-\mathrm{CH}_{\mathrm{x}}$ species $\left(\tau_{\mathrm{CHx}}, \mathrm{s}\right)$ leading to $\mathrm{CH}_{4}$, was found to increase $\sim 2.5$ times by increasing the $\mathrm{CO}$ feed gas concentration from 3 to $5 \mathrm{vol} \%$, whereas a further increase to $7 \mathrm{vol} \%$ causes only a slight increase $(\sim 30 \%)$. This result agrees very well with previous works. More specifically, $\tau_{\mathrm{CHx}}$ is in the range of $5-15 \mathrm{~s}$ for the present catalytic system and the FTS reaction conditions applied, which is similar to other previous SSITKA works over Co-based catalysts supported on $\mathrm{SiO}_{2}$ or $\mathrm{Al}_{2} \mathrm{O}_{3}$, where $\tau_{\mathrm{CHx}}$ ranged from 8 to $25 \mathrm{~s}[8,11,15,16,59]$. Vada et al. [58] for Co supported on alumina carrier found that, by decreasing the $\mathrm{H}_{2} / \mathrm{CO}$ gas ratio, the $\tau_{\mathrm{CHx}}$ increases $(7,13$, and $29 \mathrm{~s}$ for $\mathrm{H}_{2} / \mathrm{CO}=15,10$, and 5 , respectively, $\mathrm{CO}=2 \mathrm{vol} \%$ ). This result is in harmony with those of the present work. However, it should be noted that, in that work [58], the effect of $\mathrm{H}_{2} / \mathrm{CO}$ gas ratio was investigated by varying the $\mathrm{P}_{\mathrm{H} 2}$ as opposed to the present work where the $\mathrm{P}_{\mathrm{CO}}$ varied and $\mathrm{P}_{\mathrm{H} 2}$ was kept constant (Figure 3A).

According to the results shown in Table 1, the $\mathrm{TOF}_{\text {chem }}\left(\mathrm{s}^{-1}\right)$ for $\mathrm{CH}_{4}$ formation at $230{ }^{\circ} \mathrm{C}$ decreases by $\sim 25 \%$ when the $\mathrm{P}_{\mathrm{CO}}$ increases from 36 to 84 mbar. A similar behaviour was reported for the methanation reaction at $260{ }^{\circ} \mathrm{C}$ on $\mathrm{Co} / \mathrm{SiO}_{2}\left(\mathrm{P}_{\mathrm{H} 2}=450 \mathrm{mbar}\right)$ [18]. The drop in TOF of $\mathrm{CH}_{4}$ formation is attributed to the deterioration of site activity $\left(\mathrm{k}_{\mathrm{eff}}\right)$ of the $-\mathrm{CH}_{\mathrm{x}}$ species and not of a possible decrease of the surface coverage of $-\mathrm{CH}_{\mathrm{x}}$, as illustrated in Table 2. Given the fact that $\mathrm{k}_{\text {eff }}=\mathrm{k} \theta_{\mathrm{H}}$ (see Section 4.2), it is reasonable to suggest that, as $\theta_{\mathrm{H}}$ decreases with increasing $\mathrm{P}_{\mathrm{CO}}$, then deterioration of intrinsic activity $(\mathrm{k})$ of $-\mathrm{CH}_{\mathrm{x}}$ should be considered less than $25 \%$ in that range of $\mathrm{P}_{\mathrm{CO}}$. Weststrate and Niemantsverdriet [46] pointed out the importance of $\theta_{\mathrm{CHx}}$ and $\theta_{\mathrm{V}}$ (coverage of empty catalytic sites) for hydrogen adsorption related to the hydrogenation of $\mathrm{CO}$ toward methane formation. The surface 
coverage of CO-s defines the amount of hydrogen able to chemisorb next to adsorbed CO-s for a given $\mathrm{P}_{\mathrm{CO}}$, and, as a consequence, the $\tau_{\mathrm{CHx}}$ strongly depends on the $\mathrm{H}_{2} / \mathrm{CO}$ gas ratio [46,58].

The TOF $\mathrm{TTK}_{\text {ITK }}\left(\mathrm{s}^{-1}\right)$ of $\mathrm{CH}_{4}$ formation estimated based on the active $\mathrm{CO}-\mathrm{s}$ and $\mathrm{CH}_{\mathrm{x}}$-s intermediates measured by SSITKA shows large differences when compared to $\mathrm{TOF}_{\text {chem }}$ for a given $\mathrm{P}_{\mathrm{CO}}$, according to the results reported in Table 1 . The influence of $\mathrm{P}_{\mathrm{CO}}$ on $\mathrm{TOF}_{\mathrm{ITK}}$ is largely different than in the case of $\mathrm{TOF}_{\text {chem. }}$. By increasing the $\mathrm{CO}$ partial pressure from 36 to 84 mbar, the TOF $\mathrm{TTK}_{\text {IT }}$ decreases by a factor of 2.9 (127.7 vs. $\left.44.2 \times 10^{-3} \mathrm{~s}^{-1}\right)$ to be compared to the value of 1.3 for the $\mathrm{TOF}_{\text {chem, }}$, which indicates the more sensitive nature of $\mathrm{TOF}_{\text {ITK }}$ on $\mathrm{P}_{\mathrm{CO}}$. It is interesting to mention the variation of $\mathrm{TOF}_{\text {ITK}} / \mathrm{TOF}_{\text {chem }}$ with $\mathrm{P}_{\mathrm{CO}}$, where a decrease from 13 to 6 is obtained by increasing the $\mathrm{P}_{\mathrm{CO}}$ from 36 to 84 mbar.

The exchange rates of $\mathrm{CO}-\mathrm{s}$ and $\mathrm{CH}_{\mathrm{x}}-\mathrm{s}$ in the SSITKA experiment were estimated (see Section 4.2, Equations (3) and (4)) and reported (Figure 2) for the first time to the best of our knowledge. It is clearly illustrated the significantly larger adsorption/desorption rate of $\mathrm{CO}, R_{\mathrm{CO}}^{e x}$, compared to that of hydrogenation of $-\mathrm{CH}_{\mathrm{x}}\left(R_{\mathrm{CHx}}^{e x}\right)$ under working FTS reaction conditions (5-7 vol\% $\mathrm{CO}$ in the feed), but the similar rates for the lowest feed concentration of $3 \mathrm{vol} \% \mathrm{CO}$. Furthermore, the shape profile of $R_{C H x}^{e x}$ suggests the influence of $\mathrm{P}_{\mathrm{CO}}$ on the formation of different kinds of $\mathrm{CH}_{\mathrm{x}}-\mathrm{s}$ in the methanation reaction path with different reactivity toward hydrogenation to methane. Bell and co-workers [61] were the first to describe an advanced mathematical analysis of the ${ }^{13} \mathrm{CH}_{4}$-SSITKA response curve for the methanation reaction, which reveals the distribution of reactivity of $-\mathrm{CH}_{\mathrm{x}}-\mathrm{s}(\mathrm{f}(\mathrm{k})$-reactivity distribution function). Thus, the heterogeneity of sites exists for this particular active reaction intermediate. Weststrate and Niemantsverdriet [46] pointed out that the long $\mathrm{CH}_{\mathrm{x}}$-s residence time (e.g., $10 \mathrm{~s}$ ) observed on the $\mathrm{Co}(0001)$ surface, which is similar to the $\tau_{\mathrm{CHx}}$ values reported in Table 1 , cannot be due to the existence of low values of $\theta_{\mathrm{H}}$ or $\theta_{\mathrm{H}} / \theta_{*} \mathrm{H}$, where $\theta_{*} \mathrm{H}$ is the surface coverage of empty sites for hydrogen chemisorption. The authors proposed, based on DFT calculations and the $\theta_{\mathrm{CHx}}$ values observed (0.1-0.2 ML), that $\mathrm{CH}_{\mathrm{x}}$ are formed on step edge sites, which then migrate to the terrace sites. The latter was considered the rate-determining step (RDS) that gives rise to residence times of $\sim 10 \mathrm{~s}$. Given the fact that more than one kind of step edge sites can be formed on the Co surface with a distribution that depends on the Co particle size, hydrogenation of such $\mathrm{CH}_{\mathrm{x}}$-s species is more sensitive to the $\mathrm{P}_{\mathrm{CO}}$, which is shown in the present work (Figure 2B). An increase of $\mathrm{CO}$ feed gas concentration from 3 to $7 \mathrm{vol} \%$ causes the increase of $\tau_{\mathrm{CHx}}$ by $\sim 3.5$ times (Table 1 ).

\subsection{The Influence of $\mathrm{H}_{2}$ Partial Pressure on the Reactivity of $\mathrm{CO}-\mathrm{s}$ in the Methanation Reaction}

Transient Isothermal Hydrogenation (TIH) of adsorbed CO-s coupled with DRIFTS performed at $200{ }^{\circ} \mathrm{C}$ after $2 \mathrm{~h}$ in $5 \mathrm{vol} \% \mathrm{CO} / 25 \mathrm{vol} \% \mathrm{H}_{2} / \mathrm{Ar}$ along with microkinetic analysis, which was based on a hydrogen-assisted $\mathrm{CO}$ hydrogenation mechanism, revealed practically the same reactivity $(\mathrm{k})$ for each of the two $\mathrm{L}_{1}$ and $\mathrm{L}_{2}$ linear-type adsorbed CO-s species populated on the present $\mathrm{Co} / \gamma-\mathrm{Al}_{2} \mathrm{O}_{3}$ catalyst (Figure $7 \mathrm{C}, \mathrm{D}$ ). According to the results depicted in Figures $6 \mathrm{C}$ and $7 \mathrm{C}$, the initial surface coverage of $\mathrm{L}_{1}$ and $\mathrm{L}_{2}$ adsorbed CO-s is largely different. The $\theta_{\mathrm{CO}}$ apparently had no influence on the hydrogenation activity of each of these two linear-type CO-s, thus, on the RDS (HCO-s + H-s $\rightarrow$ $\mathrm{HCOH}-\mathrm{s}+\mathrm{s}$ ), in agreement with the recent work of Zijlstra et al. [34]. The authors based on Density Functional Theory (DFT) calculations reported that the C-O bond dissociation energy on step-edge sites is hardly affected by $\mathrm{CO}$ co-adsorbates. The comparison between the $\mathrm{CO}$-s hydrogenation rate constant (k) found in the present work (Figure 7, Section 2.4) for a $\mathrm{H}_{2} / \mathrm{CO}$ gas ratio of 5 and that from previous results [19] for a $\mathrm{H}_{2} / \mathrm{CO}$ gas ratio of 2 (same $5 \% \mathrm{CO}$ concentration was used in the FTS reaction) over the same catalyst, suggest that the $\mathrm{H}_{2} / \mathrm{CO}$ gas ratio hardly affects the $\mathrm{k}$ of RDS (H-assisted CO hydrogenation mechanism).

The results of the operando DRIFTS-Mass spectrometry methodology applied in the isothermal hydrogenation of adsorbed CO-s and in the transient mode, which are depicted in Figures 6-8, combined with the SSITKA-MS results depicted in Figure 3B, allowed to learn about the nature of the various kinds of adsorbed CO-s, their distribution (individual $\left.\theta_{\mathrm{CO}}\left(\mathrm{L}_{\mathrm{i}}\right), \mathrm{i}=1,2\right)$, and their reactivity $\left(\mathrm{k}_{\mathrm{i}}, \mathrm{s}^{-1}\right)$ toward hydrogenation to $\mathrm{CH}_{4}$. On the other hand, the SSITKA-MS alone and the TIH-Mass 
spectrometry alone (Figure 4B) allowed to estimate only the total surface coverage of all types of CO-s and an effective reactivity, $\mathrm{k}_{\text {eff }}\left(\mathrm{s}^{-1}\right)$ for methanation associated with the active $\mathrm{CH}_{\mathrm{x}}$-s formed from all these related adsorbed CO-s precursor species. Thus, the powerful combination of SSITKA with an operando methodology becomes clear from the results of the present example of methanation reaction on $\mathrm{Co} / \gamma-\mathrm{Al}_{2} \mathrm{O}_{3}$, as demonstrated also in the WGS reaction and others reported therein [24].

\subsection{Effect of $C O$ Partial Pressure on the Formation of Inactive $C_{\beta}$ and $C_{\gamma}$ Carbonaceous Species}

Transient isothermal (TIH) and temperature programmed hydrogenation (TPH) conducted following the SSITKA step-gas switch $\left({ }^{12} \mathrm{CO} / \mathrm{H}_{2} \rightarrow{ }^{13} \mathrm{CO} / \mathrm{H}_{2}\right)$ over alumina-supported cobalt for the first time was described in detail in our previous publication [19]. In the present work, the influence of $\mathrm{CO}$ partial pressure in the 36-84 mbar range (constant $\mathrm{H}_{2}$ partial pressure of $300 \mathrm{mbar}$ ) on the rate of formation of inactive carbonaceous species (based on the measured amount for a given time-on-stream, TOS) was investigated. The transient rate of ${ }^{12} \mathrm{CH}_{4}$ formation estimated during TIH at $230{ }^{\circ} \mathrm{C}$ (Figure $4 \mathrm{~A}$ ) corresponds to the hydrogenation of inactive $\mathrm{C}_{\beta}, \mathrm{C}_{\mathrm{x}} \mathrm{H}_{\mathrm{y}}-\mathrm{s}(\mathrm{y} \neq 0)$, the structure of which was revealed via in situ DRIFTS [19], which is in agreement with other studies on Co-based FTS catalysts at similar reaction temperatures $[46,62]$.

The amount of $C_{\beta}$ (Table 2) was found to be 1.2 and 1.1 times higher in the case where $3 \mathrm{vol} \% \mathrm{CO}$ compared to 5 and $7 \mathrm{vol} \% \mathrm{CO}$, respectively, were used (34.3, 27.6, and $30.4 \mu \mathrm{mol} \mathrm{C} \mathrm{g}^{-1}$, respectively). The shape of ${ }^{12} \mathrm{CH}_{4}$ response (Figure $\left.4 \mathrm{~A}\right)$ revealed two kinds of inactive $\mathrm{C}_{\beta}$ species $\left(\mathrm{C}_{\beta}, \mathrm{I}\right.$ - small peak at $\sim 5 \mathrm{~s}$, and $\mathrm{C}_{\beta}, \mathrm{II}-$ broad peak with maximum at $\sim 30 \mathrm{~s}$ ) in the case where $3 \mathrm{vol} \% \mathrm{CO}$ was used in the feed gas stream, as opposed to the case of 5 and $7 \mathrm{vol} \% \mathrm{CO}$, where only single and very similar in shape peaks were observed, which likely correspond to adsorbed carbonaceous species of the same chemical structure. Based on our previous DRIFTS work [19] and the results of Figure 4A (peak shapes), the $\mathrm{C}_{\beta}$, I-small peak could be attributed to the presence of a small concentration of HCOO-s (formate species) formed on the Co-alumina interface able to be hydrogenated at $230{ }^{\circ} \mathrm{C}$. This assignment finds support from the TIH experiments reported by Paredes et al. [23].

The rate of hydrogenation of CO-s and active $\mathrm{CH}_{x}-\mathrm{s}$ (Figure 4B) is significantly larger than that of inactive $\mathrm{C}_{\beta}\left({ }^{12} \mathrm{CH}_{4}\right.$ response, Figure $\left.4 \mathrm{~A}\right)$, and this explains the accumulation of $\mathrm{C}_{\beta}$ in $\mathrm{CO} / \mathrm{H}_{2}$ reaction conditions, where $\theta_{\mathrm{H}}$ is lower than that established in $50 \% \mathrm{H}_{2} / \mathrm{Ar}$ gas treatment. In the former case, $\mathrm{CO}$ and $\mathrm{H}_{2}$ competes for $\mathrm{Co}$ active sites, where the former presents larger adsorption energy. Thus, $\theta_{\mathrm{CO}}$ will depend largely on the partial pressure of $\mathrm{CO}$ only, as opposed to $\theta_{\mathrm{H}}$, which will also depend on the concentration of Co surface vacant sites [18]. As mentioned previously (see Section 3.1), by reducing $\theta_{\mathrm{H}}$, the concentration of active $\mathrm{CH}_{\mathrm{x}}$-s formed will be reduced. As shown in Table 2 and Figure 4, with decreasing $\mathrm{CO}$ partial pressure in the feed gas stream (ca. $3 \mathrm{vol} \%$ ), $\theta_{\mathrm{CO}}$ and $\theta_{\mathrm{CHx}}$ become smaller (Figure $3 \mathrm{~B}$ ), which leads to less blockage of Co active sites for $\mathrm{H}$-s formation. Thus, more $\mathrm{C}_{\beta}$ can be formed. The latter finds support from the literature [17], where $-\mathrm{CH}_{\mathrm{x}}$ monomers polymerization and termination $\left(\mathrm{C}_{\beta}\right.$ formation) proceed with faster rates than the $\mathrm{H}$-assisted $\mathrm{CO}$ dissociation step at FTS reaction conditions. Based on the amounts of $C_{\beta}$ (Table 2), the effect of $P_{C O}$ is not that large. Approximately, a $15 \%$ decrease occurs by increasing the $\mathrm{P}_{\mathrm{CO}}$ from 36 to $84 \mathrm{mbar}$ at $230{ }^{\circ} \mathrm{C}$ on the present $\mathrm{Co} / \gamma-\mathrm{Al}_{2} \mathrm{O}_{3}$ commercially relevant catalyst.

The TPH results shown in Figure 5A,B, Table 2, and Table S1 (ESI) reveal the likely existence of four kinds of carbonaceous species of different distribution but of similar individual activity (note the similar $\mathrm{T}_{\mathrm{M}}$ values, Table S1), independent of $\mathrm{CO}$ partial pressure. The surface coverage of each of these $\mathrm{C}_{\gamma}$ carbonaceous species largely depends on $\mathrm{P}_{\mathrm{CO}}$ (Table 2). By increasing the $\mathrm{CO}$ feed concentration from 3 to $7 \mathrm{vol} \%$, the total amount of $C_{\gamma}$ was nearly increased by a factor of two (Table 2). The chemical structure of $C_{\gamma}$ was reported [31,32,34] to include: (i) oligomeric strongly adsorbed hydrocarbon species (peaks 1,2 , and $3, \mathrm{~T}_{\mathrm{M}}=320-390{ }^{\circ} \mathrm{C}$ ) and (ii) polymeric carbon (Peak $4, \mathrm{~T}_{\mathrm{M}}=400-450{ }^{\circ} \mathrm{C}$ ). The latter species were not eliminated during DRIFTS-TIH at $230{ }^{\circ} \mathrm{C}$ as reported in our previous publication [19] (IR band centred at $\left.2915 \mathrm{~cm}^{-1}\right)$, but at higher temperatures $\left(230<\mathrm{T}<400{ }^{\circ} \mathrm{C}\right.$ ). It was reported [63] that larger amounts of polymeric carbon are formed with decreasing hydrogen partial 
pressure at constant $\mathrm{P}_{\mathrm{CO}}$ over Co-based FTS catalysts. The possibility that formates could be considered as part of $C_{\gamma}$ should be excluded, as these were hydrogenated under DRIFTS-TPH at $\mathrm{T}<300{ }^{\circ} \mathrm{C}$ [19].

Pena et al. [60] in support of the present findings showed that, by increasing the $\mathrm{H}_{2} / \mathrm{CO}$ gas ratio, higher amounts of polymeric carbon reacted with hydrogen under TPH. Keyvanloo et al. [33] showed via TPH following FTS reaction under industrial conditions that, by increasing the $\mathrm{H}_{2} / \mathrm{CO}$ ratio at a constant hydrogen partial pressure, more hydrogenated polymeric carbon was formed, which is similar to the present findings, where $\mathrm{C}_{\gamma}$ is larger in the case of $7 \mathrm{vol} \% \mathrm{CO}$ with most of carbonaceous species to be hydrogenated at $\mathrm{T}>350{ }^{\circ} \mathrm{C}$ but lower than $550{ }^{\circ} \mathrm{C}$. Thus, this cannot be attributed to atomic (low Ts) or graphitic carbon (high Ts). It was reported $[33,64]$ that, by increasing $\mathrm{P}_{\mathrm{CO}}$ at constant $\mathrm{P}_{\mathrm{H} 2}$, the deactivation rate increases, which might be due to the increase of hydrogen-deficient polymeric inactive carbonaceous species. Additionally, Pena and co-workers $[60,65]$ showed via TPH and Scanning Transmission Electron Microscopy-Electron Energy Loss Spectroscopy (STEM-EELS) that, under low hydrogen partial pressures in FTS reaction conditions, more stable carbon species are formed with polymeric carbon and strongly adsorbed hydrocarbon-like species to be responsible for the deactivation of the catalyst at a lower $\mathrm{H}_{2} / \mathrm{CO}$ gas ratio. This result agrees with the present work where, at a lower $\mathrm{H}_{2} / \mathrm{CO}$ gas ratio, larger amounts of $\mathrm{C}_{\gamma}$ are formed.

\section{Materials and Methods}

\section{1. $\mathrm{Co} / \gamma-\mathrm{Al}_{2} \mathrm{O}_{3}$ Catalyst-Synthesis and Characterization}

The $20 \mathrm{wt} \%$ Co supported on Sasol Germany's Puralox SCCa $\gamma-\mathrm{Al}_{2} \mathrm{O}_{3}$ catalyst was prepared by SASOL S.A., as described elsewhere [19,42]. More precisely, $20 \mathrm{wt} \%$ Co and $0.05 \mathrm{wt} \% \mathrm{Pt}$ were deposited on the alumina support via a slurry-phase impregnation procedure with aqueous metal precursor solutions described in References [42,43]. The resulting slurry was dried under vacuum and calcined in static air at $250^{\circ} \mathrm{C}$. Sequential impregnation and calcination steps were applied in order to achieve $20 \mathrm{wt} \%$ Co nominal loading. Prior to any catalytic and transient kinetic measurements, the catalyst was in situ reduced in pure $\mathrm{H}_{2}\left(1 \mathrm{bar}, 50 \mathrm{NmL} \mathrm{min}{ }^{-1}\right)$ at $425^{\circ} \mathrm{C}$ for $10 \mathrm{~h}$ (from room $\mathrm{T}$ to $425^{\circ} \mathrm{C}$, the temperature of the solid was increased at $\beta=1{ }^{\circ} \mathrm{C} \mathrm{min}^{-1}$ ), which was followed by an He-purge and cooling to $230{ }^{\circ} \mathrm{C}$ for FTS. A $5 \mathrm{vol} \% \mathrm{O}_{2} / \mathrm{He}(2 \mathrm{~h})$ was applied at $30^{\circ} \mathrm{C}$, following catalytic measurements, for catalyst passivation. The latter sample was further used in DRIFTS studies (Section 4.4). The as-received commercially relevant catalyst in powder form was sieved to less than a 106- $\mu \mathrm{m}$ particle size for avoidance of internal mass transport resistances before catalytic and transient kinetic measurements. Textural (BET/BJH), structural (PXRD, HAADF-TEM), and $\mathrm{H}_{2}-\mathrm{TPR} / \mathrm{H}_{2}-\mathrm{TPD}$ studies over the examined catalyst were described and presented in detail in our previous publication [19].

\subsection{SSITKA-MS Following $5 \mathrm{~h}$ in FTS}

Steady State Isotopic Transient Kinetic Analysis (SSITKA) experiments with the use of ${ }^{13} \mathrm{CO}$ were conducted in order to investigate the effects of the variation of $\mathrm{CO}$ partial pressure (constant $\mathrm{H}_{2}$ partial pressure), or the $\mathrm{H}_{2} / \mathrm{CO}$ gas ratio, on the carbon pathway of methane formation at $230^{\circ} \mathrm{C}$. After $5 \mathrm{~h}$ in $\mathrm{CO} / \mathrm{H}_{2}\left(\mathrm{x} \mathrm{vol} \%{ }^{12} \mathrm{CO} / 25 \mathrm{vol} \% \mathrm{H}_{2} / \mathrm{Ar}\right.$, GHSV $\left.=30,000 \mathrm{~h}^{-1}\right)$, the SSITKA step-gas switch to $\mathrm{x} \mathrm{vol} \%$ ${ }^{13} \mathrm{CO} / 25 \mathrm{vol} \% \mathrm{H}_{2} / \mathrm{Ar}(\mathrm{t})$ was made. At this point, it is worth mentioning that internal and external mass transport resistances in the catalytic bed placed in the quartz micro-reactor used were absent, as previously reported $[19,66]$. During the SSITKA step-gas switch, the mass numbers $(\mathrm{m} / \mathrm{z}) 15,17$, $18,28,29$, and 84, which correspond to ${ }^{12} \mathrm{CH}_{4},{ }^{13} \mathrm{CH}_{4}, \mathrm{H}_{2} \mathrm{O},{ }^{12} \mathrm{CO},{ }^{13} \mathrm{CO}$, and $\mathrm{Kr}$, respectively, were continuously monitored by MS. The contribution of $\mathrm{H}_{2} \mathrm{O}(\mathrm{m} / \mathrm{z}=18)$ to the $\mathrm{m} / \mathrm{z}=17$ was considered for the analysis of ${ }^{13} \mathrm{CH}_{4}$ signal to concentration (ppm or mol\%) in the case a different signal at $\mathrm{m} / \mathrm{z}=18$ in the two ${ }^{12} \mathrm{CO} / \mathrm{H}_{2}$ and ${ }^{13} \mathrm{CO} / \mathrm{H}_{2}$ gas mixtures would be recorded. An ideally designed and conducted ${ }^{12} \mathrm{CO} /{ }^{13} \mathrm{CO}-S S I T K A$ experiment for FTS should provide the same signals at $\mathrm{m} / \mathrm{z}=18$ [19,21]. 
The transient rates $\left(\mu \mathrm{mol} \mathrm{g}{ }^{-1} \mathrm{~s}^{-1}\right)$ of $\mathrm{CO}$ and active $\mathrm{CH}_{\mathrm{x}}$-s intermediates which are exchanged ( ${ }^{12} \mathrm{CO}$-s is replaced for ${ }^{13} \mathrm{CO}-\mathrm{s}$ and ${ }^{12} \mathrm{CH}_{\mathrm{x}}$-s for ${ }^{13} \mathrm{CH}_{\mathrm{x}}-\mathrm{s}$ ) during SSITKA were estimated based on Equations (3) and (4), respectively.

$$
\begin{aligned}
& R_{C O}^{e x}\left(m^{2} l_{g}^{-1} s^{-1}\right)=\frac{F_{T} y_{C O}^{f}}{W}\left[A-\left(X_{C O}^{s . s}\left(S_{C_{4}} Z_{13} C_{4}(t)+S_{C 2} Z_{C 2}(t)+S_{C 3} Z_{C 3}(t)+\ldots\right)\right)\right] \\
& R_{C H x}^{e x}\left(m o l g-1 s^{-1}\right)=\frac{F_{T} y_{13} C_{4}}{W}\left[Z_{13} \mathrm{CO}(t)-Z_{13} C_{4}(t)\right]
\end{aligned}
$$

where $F_{T}$ is the total molar flow rate $\left(\mathrm{mol} \mathrm{s}^{-1}\right), y_{\mathrm{CO}}$ is the mole fraction of $C O$ in the feed, $X_{C O}^{s . s}$ is the $\mathrm{CO}$ conversion (\%) at a steady state, $\mathrm{W}$ is the mass of the catalyst $(\mathrm{g}), y_{13 \mathrm{CH} 4}$ is the mole fraction of ${ }^{13} \mathrm{CH}_{4}$ at the effluent stream from the micro-reactor in the new steady-state obtained in ${ }^{13} \mathrm{CO} / \mathrm{H}_{2}, \mathrm{Z}$ is the dimensionless concentration of a given gas-phase species, and $A(t)=\left(Z_{K r}(t)-Z_{13} \mathrm{CO}(t)\right)$.

Equation (3) is based on the fact that the rate of ${ }^{13} \mathrm{CO}$ fed in the reactor $\left(\mathrm{mols}{ }^{13} \mathrm{CO} / \mathrm{s}\right)$ during the step-gas SSITKA switch (until the new steady-state is reached) must be equal to the sum of the rates of: (i) exchange of ${ }^{13} \mathrm{CO}$ with ${ }^{12} \mathrm{CO}$-s $\left(R_{C O}^{e x}\right.$ ), (ii) conversion of ${ }^{13} \mathrm{CO}$ into ${ }^{13} \mathrm{CH}_{4}$, (iii) conversion of ${ }^{13} \mathrm{CO}$ into ${ }^{13} \mathrm{C}_{2+}$-hydrocarbons, and (iv) the rate of non-reacted ${ }^{13} \mathrm{CO}(\mathrm{g})$ leaving the reactor (rate of outlet flow of ${ }^{13} \mathrm{CO}(\mathrm{g})$ from the micro-reactor). The $\mathrm{Z}_{\mathrm{C} 2}, \mathrm{Z}_{\mathrm{C} 3}$, and those of higher hydrocarbons $\left(\mathrm{Z}_{\mathrm{Cn}}\right)$ that appear in Equation (3) represent the fractional change in ${ }^{13} \mathrm{C}$ for the $\mathrm{C}_{2^{-}}, \mathrm{C}_{3^{-}}$, and $\mathrm{C}_{\mathrm{n}}$-hydrocarbons, respectively, and can only be measured after using the SSITKA-GS-MS methodology $[17,67]$. In the present work, only the $\left.\mathrm{Z}_{\mathrm{C} 1}\left(\mathrm{Z}^{13} \mathrm{CH}_{4}\right)\right)$ was measured by mass spectrometry. However, according to the experimental work of Rebmann et al. [67] on a $13 \mathrm{wt} \% \mathrm{Co} / \gamma-\mathrm{Al}_{2} \mathrm{O}_{3}$ catalyst, the $\mathrm{Z}_{\mathrm{C} 2}$ and $\mathrm{Z}_{\mathrm{C} 3}$ transient curves were very close (almost identical) to that of $Z_{\mathrm{C} 1}$. Given the fact that, in the present work, the total carbon selectivity to $C_{1}-C_{3}$ is more than $85 \%$, the $Z_{C n}(n>3)$ terms in Equation (3) were neglected, and it was considered that $Z_{\mathrm{C} 1} \sim Z_{\mathrm{C} 2} \sim Z_{\mathrm{C} 3}$. In Equations (3) and (4), the accumulation of ${ }^{13} \mathrm{CO}(\mathrm{g})$ in the CSTR micro-reactor used [66] was found to be very small when compared to the other terms. Thus, it was also neglected.

The concentration $\left(\mu \mathrm{mol} \mathrm{g}^{-1}\right)$ of the reversibly adsorbed CO-s and active $\mathrm{CH}_{\mathrm{x}}$-s intermediates leading to $\mathrm{CH}_{4}$ are given by the following material balance Equations (5) and (6), respectively [19].

$$
\begin{gathered}
N_{\mathrm{CO}}\left(m \lg ^{-1}\right)=\frac{F_{T} y_{\mathrm{CO}}^{f}\left(1-X_{\mathrm{CO}}\right)}{W} \int_{0}^{t_{s . s}}\left[Z_{K r}(t)-Z_{13 \mathrm{CO}}(t)\right] d t \\
N_{\mathrm{CH} x}\left(m \operatorname{molg}^{-1}\right)=\frac{F_{T} y^{13} \mathrm{CH}_{4}}{W} \int_{0}^{t_{s . s}}\left[Z_{13} \mathrm{CO}(t)-Z_{13} \mathrm{CH}_{4}(t)\right] d t
\end{gathered}
$$

The surface coverage, $\theta$, and the mean residence time, $\tau(\mathrm{s})$, of the reversibly adsorbed CO-s and active $\mathrm{CH}_{\mathrm{x}}$-s intermediates, can be estimated based on the following Equations (7)-(9).

$$
\begin{aligned}
\theta_{i} & =\frac{N_{i}}{N_{C o, \text { surf }}}\left(i=C O, C_{x}\right) \\
\tau_{C O} & =\int_{0}^{t_{\text {s.s }}}\left[Z_{K r}(t)-Z_{13 \mathrm{CO}}(t)\right] d t \\
\tau_{\mathrm{CH} x} & =\int_{0}^{t_{\text {s.s }}}\left[\mathrm{Z}_{13 \mathrm{CO}}(t)-\mathrm{Z}_{{ }^{13} \mathrm{CH}_{4}}(t)\right] d t
\end{aligned}
$$

where $t_{\text {s.s. }}$ is the time at which the new steady-state is obtained under the ${ }^{13} \mathrm{CO} / \mathrm{H}_{2}$ gas mixture. 
The kinetic rate TOF $\left(\mathrm{s}^{-1}\right)$ of $\mathrm{CH}_{4}$ formation is estimated based on the Co dispersion, Equation (10) $\left(T O F_{\text {chem }}, \mathrm{s}^{-1}\right)$, or the concentration of active reaction intermediates (Equations (5) and (6)) found in the reaction path of $\mathrm{CH}_{4}$ formation, $\mathrm{TOF}_{\text {ITK }}\left(\mathrm{s}^{-1}\right)$, via Equation (11) [19]. In addition, the effective rate constant, $k_{\text {eff }}\left(\mathrm{s}^{-1}\right)$, for the methanation reaction is estimated based on Equation (12), which holds when one of the hydrogenation steps of $-\mathrm{CH}_{\mathrm{x}} / \mathrm{CH}_{\mathrm{x}} \mathrm{O}$ intermediates is the $\mathrm{RDS}$ of the methanation reaction (hydrogenation and not $\mathrm{CO}$ dissociation of CO-s is the RDS).

$$
\begin{aligned}
T O F_{\text {Chem }} & =\frac{F_{T} y_{C_{4}}}{W N_{C o, \text { surf }}}=\frac{\theta_{C H x}}{\tau_{C H x}} \\
T O F_{I T K} & =\frac{F_{T} y_{C H_{4}}}{W\left(N_{C O}+N_{C H x}\right)} \\
k_{\text {eff }} & =\frac{1}{\tau_{C H x}}=k \theta_{H}
\end{aligned}
$$

$\mathrm{N}_{\mathrm{Co} \text {,surf }}$ is the total number of surface cobalt per gram of catalyst $\left(\mu \mathrm{mol} \mathrm{g}{ }^{-1}\right)$ estimated on the basis of the dispersion and loading values of the $\mathrm{Co} / \gamma-\mathrm{Al}_{2} \mathrm{O}_{3}$ catalyst.

\subsection{Transient Isothermal (TIH) and Temperature-Programmed Hydrogenation (TPH) Experiments}

Transient hydrogenation experiments (Isothermal and Temperature-Programmed) were performed following the SSITKA step-gas switch: $\mathrm{x} \%{ }^{13} \mathrm{CO} / 25 \% \mathrm{H}_{2} / \mathrm{Kr} / \mathrm{Ar}\left(230{ }^{\circ} \mathrm{C}, 7 \mathrm{~min}\right) \rightarrow \operatorname{Ar}(3 \mathrm{~min}) \rightarrow 50 \%$ $\mathrm{H}_{2} / \mathrm{Ar}$, TIH $\left(7 \mathrm{~min}, 230^{\circ} \mathrm{C}\right) \rightarrow \mathrm{TPH}$ up to $600^{\circ} \mathrm{C}\left(\beta=10^{\circ} \mathrm{C} \mathrm{min}{ }^{-1}\right)$. During the TIH and TPH runs, the mass numbers $(\mathrm{m} / \mathrm{z}) 15,17$, and 18 for ${ }^{12} \mathrm{CH}_{4},{ }^{13} \mathrm{CH}_{4}$, and $\mathrm{H}_{2} \mathrm{O}$ were continuously monitored by online mass spectrometry. Under $\mathrm{TIH}$ at $230{ }^{\circ} \mathrm{C}$, the ${ }^{12} \mathrm{CH}_{4}$ response reflects the inactive carbon-containing species (named $\mathrm{C}_{\beta}$ ) formed during the non-isotopic ${ }^{12} \mathrm{CO} / \mathrm{H}_{2}$ gas mixture $(5 \mathrm{~h})$ and which cannot be exchanged with ${ }^{13} \mathrm{CO}$ during the ${ }^{13} \mathrm{CO} / \mathrm{H}_{2}$-SSITKA switch. On the other hand, the ${ }^{13} \mathrm{CH}_{4}$ response reflects both the adsorbed ${ }^{13} \mathrm{CO}-\mathrm{s}$ and active ${ }^{13} \mathrm{CH}_{\mathrm{x}}$-s species that are exchanged during the SSITKA switch. Under TPH, the response of ${ }^{12} \mathrm{CH}_{4}$ is due to adsorbed refractory carbonaceous inactive species $\left(\mathrm{C}_{\mathrm{x}} \mathrm{H}_{\mathrm{y}}\right.$-s, named $\left.\mathrm{C}_{\gamma}\right)$ that were not hydrogenated at $230^{\circ} \mathrm{C}$. The transient concentration response curves of ${ }^{12} \mathrm{CH}_{4}(\mathrm{t})$ and ${ }^{13} \mathrm{CH}_{4}(\mathrm{t})$ recorded during TIH/TPH were converted into transient rates $\left(\mathrm{mol} \mathrm{g}^{-1} \mathrm{~s}^{-1}\right)$ using Equation (13) (the accumulation term in the Continuous Stirred Tank Reactor (CSTR, $1.5 \mathrm{~mL}$ volume micro-reactor) was found negligible when compared to the outlet rate of $\mathrm{CH}_{4}$ from the micro-reactor) and after calibration of the MS signal with standard $1.04 \mathrm{~mol} \%{ }^{12} \mathrm{CH}_{4} / \mathrm{Ar}$ and $2.1 \mathrm{~mol} \%$ ${ }^{13} \mathrm{CH}_{4} /$ Ar gas mixtures.

$$
R_{\mathrm{CH}_{4}}\left(\operatorname{molg}^{-1} \mathrm{~s}^{-1}\right)=\frac{F_{T} y_{C H_{4}}}{W}
$$

\subsection{Operando DRIFTS—Mass Spectrometry—Transient Isothermal Hydrogenation (TIH) of CO}

The reactivity toward hydrogen of the various types of chemisorbed CO-s formed after $2 \mathrm{~h}$ of $\mathrm{CO} / \mathrm{H}_{2}$ reaction at $200^{\circ} \mathrm{C}$ was determined by operando DRIFTS kinetic experiments. The temperature of $200{ }^{\circ} \mathrm{C}$ instead of $230^{\circ} \mathrm{C}$ was selected since this allowed the recording of more spectra (lower hydrogenation rate of $\mathrm{CO}$ ) during this transient experiment. DRIFTS spectra were collected by using a Perkin-Elmer Frontier FT-IR spectrometer equipped with an MCT detector and a high-temperature/high pressure temperature controllable DRIFTS reactor cell (Harrick Scientific, Praying Mantis) with $\mathrm{CaF}_{2}$ windows. An average spectrum was recorded after 256 scans (resolution of $4 \mathrm{~cm}^{-1}$, scanning speed rate of $2 \mathrm{~cm} \mathrm{~s}^{-1}$ ). The sieved and passivated catalyst sample (as described in Section 4.1) was placed in the DRIFTS reactor cell $(\sim 90 \mathrm{mg})$ and its temperature was increased to $425^{\circ} \mathrm{C}$ and kept for $2 \mathrm{~h}$ in $50 \mathrm{vol} \% \mathrm{H}_{2} / \mathrm{Ar}\left(50 \mathrm{NmL} \mathrm{min}^{-1}\right)$, which was followed by cooling in $\mathrm{H}_{2} / \mathrm{Ar}$ gas flow to the methanation reaction temperature, $\mathrm{T}=200^{\circ} \mathrm{C}$, for background spectrum of solid catalyst acquisition. The DRIFTS cell was subsequently purged in Ar gas flow for $20 \mathrm{~min}$ and then exposed to the $\mathrm{CO} / \mathrm{H}_{2}$ feed gas stream ( $5 \mathrm{vol} \% \mathrm{CO} / 25 \mathrm{vol} \% \mathrm{H}_{2} / \mathrm{Ar}$ ) for $2 \mathrm{~h}$. At the end of the reaction, an averaged DRIFTS spectrum was 
collected. The transient kinetics of hydrogenation of individual adsorbed CO-s species formed during the reaction step was investigated by transient isothermal hydrogenation (TIH) in $50 \mathrm{vol} \% \mathrm{H}_{2} / \mathrm{Ar}$ gas flow. The recorded DRIFTS spectra in the $\mathrm{CO}$ region under $\mathrm{CO} / \mathrm{H}_{2}$ and $\mathrm{TIH}$ reaction conditions were deconvoluted following the procedure previously described in detail [19]. In the case of a TIH reaction run, where no gas phase IR CO bands were observed, the following criteria for deconvolution were used: (i) FWHM $<100 \mathrm{~cm}^{-1}$, (ii) $\mathrm{R}^{2}>0.99$, and (iii) IR band center of the CO-s species was allowed for a small shift $\left(<20 \mathrm{~cm}^{-1}\right)$ to lower wavenumbers (surface coverage effect). By considering fulfillment of the above three criteria, three IR bands of adsorbed CO-s were obtained.

During $\mathrm{TIH}$, the gas-phase responses of $\mathrm{CO}$ and $\mathrm{CH}_{4}$ from the outlet of the DRIFTS reactor cell were continuously monitored by the connected mass spectrometer (MS), which were used for performing the SSITKA-MS and other transient kinetic experiments that followed (TIH/TPH).

\section{Conclusions}

The present study aimed at providing deeper fundamental understanding on how the CO partial pressure affects important kinetic parameters of the methanation reaction path at $230{ }^{\circ} \mathrm{C}$ and $1.2 \mathrm{bar}$ total pressure over a commercially relevant $20 \mathrm{wt} \% \mathrm{Co}-0.05 \mathrm{wt} \% \mathrm{Pt} / \gamma-\mathrm{Al}_{2} \mathrm{O}_{3}$ catalyst. Towards this goal, advanced SSITKA combined with transient isothermal and temperature-programmed hydrogenation experiments as well as transient operando DRIFTS-MS $\mathrm{CO}$ hydrogenation to $\mathrm{CH}_{4}$ coupled with a microkinetic modelling were performed.

For the first time, to the best of our knowledge, the exchange rates of $\mathrm{CO}-\mathrm{s}$ and $\mathrm{CH}_{\mathrm{x}}-\mathrm{s}$ related to the SSITKA experiment were estimated via strict application of ${ }^{13} \mathrm{C}$-material balances. The adsorption/ desorption rate of $\mathrm{CO}-\mathrm{s}, R_{\mathrm{CO}}^{e x}$, was found to be significantly larger in comparison to the hydrogenation of $\mathrm{CH}_{\mathrm{x}} \mathrm{-s}\left(R_{\mathrm{CHx}}^{e x}\right)$, and its dependence on the partial pressure of $\mathrm{CO}$ was probed. The large influence of $\mathrm{CO}$ partial pressure on the formation of different kinds of active $\mathrm{CH}_{\mathrm{x}}$-s during the methanation reaction was suggested by the shape of the transient rate profile of the $\mathrm{CH}_{\mathrm{x}}-\mathrm{s}$ exchange.

By increasing the $\mathrm{CO}$ partial pressure, an increase of $\theta_{\mathrm{CO}}$ was observed and this agrees with the characteristic features of the Langmuir isotherm and the fast $\mathrm{CO}$ exchange observed. Additionally, by increasing the $\mathrm{CO}$ partial pressure, an increase of $\theta_{\mathrm{CHx}}$ and a concomitant decrease in $\mathrm{S}_{\mathrm{CH} 4}$ were observed, which was linked to the increase of $\theta_{\mathrm{CO}} / \theta_{\mathrm{CHx}}$ by decreasing the $\mathrm{CO}$ partial pressure (competitive chemisorption of $\mathrm{H}_{2}$ and $\mathrm{CO}$ reactants) and the growing rate of $-\mathrm{CH}_{\mathrm{x}}$ coupling (increase of $\left.\theta_{\mathrm{CHx}}\right)$.

The amount $(\mu \mathrm{mol} / \mathrm{g})$ and reactivity in hydrogen of the inactive carbonaceous species formed after $5 \mathrm{~h}$ of FTS at $230{ }^{\circ} \mathrm{C}$ over the $\mathrm{Co} / \gamma-\mathrm{Al}_{2} \mathrm{O}_{3}$ catalyst was estimated via TIH $\left(\mathrm{C}_{\beta}\right)$ and TPH $\left(\mathrm{C}_{\gamma}\right)$ following SSITKA. The amounts of $\mathrm{C}_{\beta}$ and $\mathrm{C}_{\gamma}$ were found to be influenced by the $\mathrm{CO}$ partial pressure (36-84 mbar, $\mathrm{P}_{\mathrm{H} 2}=300$ mbar). In particular, larger amounts of adsorbed active $\mathrm{CH}_{\mathrm{x}}-\mathrm{s}$ and $\mathrm{CO}-\mathrm{s}$ were found to react with hydrogen at $230{ }^{\circ} \mathrm{C}$ toward $\mathrm{CH}_{4}$ by increasing the $\mathrm{CO}$ partial pressure, as opposed to the amount of inactive carbonaceous species $\left(-\mathrm{C}_{x} \mathrm{H}_{y}\right.$, named $\left.\mathrm{C}_{\beta}\right)$, which slightly decreased by increasing the $\mathrm{CO}$ concentration in the feed. The latter was related to the fact that $\theta_{\mathrm{CO}}$ and $\theta_{\mathrm{CHx}}$ become larger, which likely reduces the surface coverage of $\mathrm{H}-\mathrm{s}$, and, thus, the rate of formation of $\mathrm{C}_{\beta}$. The amount of inactive carbonaceous species $C_{\gamma}$ was found to significantly increase with increasing $C O$ partial pressure. The $\mathrm{C}_{\gamma}$ could be due to hydrogen-deficient polymeric carbon and strongly adsorbed hydrocarbon-like species, but not formate (HCOO), atomic, or graphitic carbon.

Based on microkinetic modelling performed on the operando DRIFTS Transient Isothermal Hydrogenation conducted at $200{ }^{\circ} \mathrm{C}$ following the methanation reaction $\left(5 \mathrm{vol} \% \mathrm{CO} / 25 \mathrm{vol} \% \mathrm{H}_{2} / \mathrm{Ar}\right.$, $2 \mathrm{~h}$ ), the presence of two linear-type adsorbed CO-s species $\left(\mathrm{L}_{1}\right.$ and $\left.\mathrm{L}_{2}\right)$ of a $65: 35(\mathrm{~mol} / \mathrm{mol})$ ratio but of very similar activity $(\mathrm{k})$ was revealed. It was concluded that $\theta_{\mathrm{CO}}$ had no influence on the hydrogenation activity of linear-type CO-s and on the RDS (HCO-s $+\mathrm{H}-\mathrm{s} \rightarrow \mathrm{HCOH}-\mathrm{s}+\mathrm{s}$ ) of the considered $\mathrm{H}$-assisted CO hydrogenation mechanism. 
Supplementary Materials: The following are available online at http://www.mdpi.com/2073-4344/10/5/583/s1, Table S1: Peak centers $\left({ }^{\circ} \mathrm{C}\right)$ of each individual peak of the TPH profiles derived after deconvolution, Table S2: IR band position $\left(\mathrm{cm}^{-1}\right)$ of each individual adsorbed CO-s $\left(\mathrm{L}_{1}\right.$ and $\left.\mathrm{L}_{2}\right)$ formed after $2 \mathrm{~h}$ in $\mathrm{FTS}(5 \% \mathrm{CO} / 25 \% \mathrm{H} / \mathrm{Ar}$, $200{ }^{\circ} \mathrm{C}$ ) recorded under Ar purge (after $3 \mathrm{~min}$ ) and in $50 \mathrm{vol} \% \mathrm{H}_{2} /$ Ar gas mixture.

Author Contributions: Conceptualization, A.M.E. and M.A.V. Methodology, A.M.E. and M.A.V. Validation, A.M.E. and M.A.V. Formal analysis, K.K.K. and M.A.V. Resources, A.M.E. and A.G. Writing-original draft preparation, M.A.V. Final writing-review and editing, A.M.E. Visualization, A.M.E. and M.A.V. Supervision, A.M.E. and M.A.V. Project administration, A.M.E. and A.G. Funding acquisition, A.M.E., N.S.G., and A.G., R.C. and D.M. All authors have read and agreed to the published version of the manuscript.

Funding: SASOL South Africa Ltd. (Contract No. 123-17-GT) and the Research Committee of the University of Cyprus funded this research.

Acknowledgments: The authors would like to acknowledge financial support from SASOL South Africa Ltd. and the Research Committee of the University of Cyprus.

Conflicts of Interest: The authors declare no conflict of interest.

\section{References}

1. Jahangiri, H.; Bennett, J.; Mahjoubi, P.; Wilson, K.; Gu, S. A review of advanced catalyst development for Fischer-Tropsch synthesis of hydrocarbons from biomass derived syn-gas. Catal. Sci. Technol. 2014, 4, 2210-2229. [CrossRef]

2. Khodakov, A.Y.; Chu, W.; Fongarland, P. Advances in the Development of Novel Cobalt Fischer-Tropsch Catalysts for Synthesis of Long-Chain Hydrocarbons and Clean Fuels. Chem. Rev. 2007, 107, 1692-1744. [CrossRef] [PubMed]

3. Chen, W.; Lin, T.; Dai, Y.; An, Y.; Yu, F.; Zhong, L.; Li, S.; Sun, Y. Recent advances in the investigation of nanoeffects of Fischer-Tropsch catalysts. Catal. Today 2018, 311, 8-22. [CrossRef]

4. Krylova, A.Y. Products of the Fischer-Tropsch synthesis (A Review). Solid Fuel Chem. 2014, 48, 22-35. [CrossRef]

5. Yang, J.; Ma, W.; Chen, D.; Holmen, A.; Davis, B.H. Fischer-Tropsch synthesis: A review of the effect of CO conversion on methane selectivity. Appl. Catal. A Gen. 2014, 470, 250-260. [CrossRef]

6. Todic, B.; Ma, W.; Jacobs, G.; Davis, B.H.; Bukur, D.B. Effect of process conditions on the product distribution of Fischer-Tropsch synthesis over a Re-promoted cobalt-alumina catalyst using a stirred tank slurry reactor. J. Catal. 2014, 311, 325-338. [CrossRef]

7. Den Breejen, J.P.; Sietsma, J.R.A.; Friedrich, H.; Bitter, J.H.; de Jong, K.P. Design of supported cobalt catalysts with maximum activity for the Fischer-Tropsch synthesis. J. Catal. 2010, 270, 146-152. [CrossRef]

8. Den Breejen, J.P.; Radstake, P.B.; Bezemer, G.L.; Bitter, J.H.; Frøseth, V.; Holmen, A.; de Jong, K.P. On the Origin of the Cobalt Particle Size Effects in Fischer-Tropsch Catalysis. J. Am. Chem. Soc. 2009, 131, 7197-7203. [CrossRef]

9. Iqbal, S.; Davies, T.E.; Hayward, J.S.; Morgan, D.J.; Karim, K.; Bartley, J.K.; Taylor, S.H.; Hutchings, G.J. Fischer Tropsch Synthesis using promoted cobalt-based catalysts. Catal. Today 2016, 272, 74-79. [CrossRef]

10. Eschemann, T.O.; Oenema, J.; de Jong, K.P. Effects of noble metal promotion for $\mathrm{Co} / \mathrm{TiO}{ }_{2}$ Fischer-Tropsch catalysts. Catal. Today 2016, 261, 60-66. [CrossRef]

11. Carvalho, A.; Ordomsky, V.V.; Luo, Y.; Marinova, M.; Muniz, A.R.; Marcilio, N.R.; Khodakov, A.Y. Elucidation of deactivation phenomena in cobalt catalyst for Fischer-Tropsch synthesis using SSITKA. J. Catal. 2016, 344, 669-679. [CrossRef]

12. Chen, W.; Kimpel, T.F.; Song, Y.; Chiang, F.K.; Zijlstra, B.; Pestman, R.; Wang, P.; Hensen, E.J.M. Influence of Carbon Deposits on the Cobalt-Catalyzed Fischer-Tropsch Reaction: Evidence of a Two-Site Reaction Model. ACS Catal. 2018, 8, 1580-1590. [CrossRef] [PubMed]

13. Efstathiou, A.M.; Gleaves, J.T.; Yablonsky, G.S. Transient Techniques: Temporal Analysis of Products and Steady State Isotopic Transient Kinetic Analysis. In Characterization of Solid Materials and Heterogeneous Catalysts: From Structure to Surface Reactivity; Wiley-VCH: Weinheim, Germany, 2012; Volume 1\&2, pp. 1013-1073.

14. Pansare, S.; Sirijaruphan, A.; Goodwin, J.G. Investigation of Reaction at the Site Level Using SSITKA. In Isotopes in Heterogeneous Catalysis, Catalytic Science Series, v. 4; Imperial College Press: London, UK, 2006; pp. 183-211. 
15. Frøseth, V.; Storsæter, S.; Borg, O.; Blekkan, E.A.; Rønning, M.; Holmen, A. Steady state isotopic transient kinetic analysis (SSITKA) of CO hydrogenation on different Co catalysts. Appl. Catal. A Gen. 2005, 289, 10-15. [CrossRef]

16. Yang, J.; Chen, D.; Holmen, A. Understanding the kinetics and Re promotion of carbon nanotube supported cobalt catalysts by SSITKA. Catal. Today 2012, 186, 99-108. [CrossRef]

17. Chen, W.; Filot, I.A.W.; Pestman, R.; Hensen, E.J.M. Mechanism of Cobalt-Catalyzed CO Hydrogenation: 2. Fischer-Tropsch Synthesis. ACS Catal. 2017, 7, 8061-8071. [CrossRef] [PubMed]

18. Chen, W.; Pestman, R.; Zijlstra, B.; Filot, I.A.W.; Hensen, E.J.M. Mechanism of Cobalt-Catalyzed CO Hydrogenation: 1. Methanation. ACS Catal. 2017, 7, 8050-8060. [CrossRef]

19. Vasiliades, M.A.; Kalamaras, C.M.; Govender, N.S.; Govender, A.; Efstathiou, A.M. The effect of preparation route of commercial $\mathrm{Co} / \gamma-\mathrm{Al}_{2} \mathrm{O}_{3}$ catalyst on important Fischer-Tropsch kinetic parameters studied by SSITKA and CO-DRIFTS transient hydrogenation techniques. J. Catal. 2019, 379, 60-77. [CrossRef]

20. Frennet, A.; de Bocarmé, T.V.; Bastin, J.-M.; Kruse, N. Mechanism and Kinetics of the Catalytic CO-H Reaction: An Approach by Chemical Transients and Surface Relaxation Spectroscopy. J. Phys. Chem. B 2005, 109, 2350-2359. [CrossRef]

21. Petallidou, K.C.; Vasiliades, M.A.; Efstathiou, A.M. Deactivation of $\mathrm{Co} / \gamma-\mathrm{Al}_{2} \mathrm{O}_{3}$ in $\mathrm{CO}$ methanation studied by transient isotopic experiments: The effect of Co particle size. J. Catal. 2020. accepted for publication.

22. Lorito, D.; Paredes-Nunez, A.; Mirodatos, C.; Schuurman, Y.; Meunier, F.C. Determination of formate decomposition rates and relation to product formation during $\mathrm{CO}$ hydrogenation over supported cobalt. Catal. Today 2016, 259, 192-196. [CrossRef]

23. Paredes-Nunez, A.; Lorito, D.; Guilhaume, N.; Mirodatos, C.; Schuurman, Y.; Meunier, F.C. Nature and reactivity of the surface species observed over a supported cobalt catalyst under $\mathrm{CO} / \mathrm{H}_{2}$ mixtures. Catal. Today 2015, 242, 178-183. [CrossRef]

24. Efstathiou, A.M. Elucidation of Mechanistic and Kinetic Aspects of Water-Gas Shift Reaction on Supported Pt and Au Catalysts via Transient Isotopic Techniques. Catalysis 2016, 28, 175-236.

25. Efstathiou, A.M.; Bennett, C.O. The $\mathrm{CO} / \mathrm{H}_{2}$ reaction on $\mathrm{Rh} / \mathrm{Al}_{2} \mathrm{O}_{3}$ : II. Kinetic study by transient isotopic methods. J. Catal. 1989, 120, 137-156. [CrossRef]

26. Kalamaras, C.M.; Americanou, S.; Efstathiou, A.M. "Redox" vs "associative formate with -OH group regeneration" WGS reaction mechanism on $\mathrm{Pt} / \mathrm{CeO}_{2}$ : Effect of platinum particle size. J. Catal. 2011, 279, 287-300. [CrossRef]

27. Kalamaras, C.M.; Gonzalez, I.D.; Navarro, R.M.; Fierro, J.L.G.; Efstathiou, A.M. Effects of Reaction Temperature and Support Composition on the Mechanism of Water-Gas Shift Reaction over Supported-Pt Catalysts. J. Phys. Chem. C 2011, 115, 11595-11610. [CrossRef]

28. Vasiliades, M.A.; Djinović, P.; Davlyatova, L.F.; Pintar, A.; Efstathiou, A.M. Origin and reactivity of active and inactive carbon formed during DRM over $\mathrm{Ni} / \mathrm{Ce}_{0.38} \mathrm{Zr}_{0.62} \mathrm{O}_{2-\delta}$ studied by transient isotopic techniques. Catal. Today 2018, 299, 201-211. [CrossRef]

29. Vasiliades, M.A.; Djinović, P.; Pintar, A.; Kovač, J.; Efstathiou, A.M. The effect of $\mathrm{CeO}_{2}-\mathrm{ZrO}_{2}$ structural differences on the origin and reactivity of carbon formed during methane dry reforming over $\mathrm{NiCo} / \mathrm{CeO}_{2}-\mathrm{ZrO}_{2}$ catalysts studied by transient techniques. Catal. Sci. Technol. 2017, 7, 5422-5434. [CrossRef]

30. Vasiliades, M.A.; Makri, M.M.; Djinović, P.; Erjavec, B.; Pintar, A.; Efstathiou, A.M. Dry reforming of methane over $5 \mathrm{wt} \% \mathrm{Ni} / \mathrm{Ce}_{1-\mathrm{x}} \mathrm{Pr}_{\mathrm{x}} \mathrm{O}_{2-\delta}$ catalysts: Performance and characterization of active and inactive carbon by transient isotopic techniques. Appl. Catal. B Environ. 2016, 197, 168-183. [CrossRef]

31. Zhuo, M.; Tan, K.F.; Borgna, A.; Saeys, M. Density Functional Theory Study of the CO Insertion Mechanism for Fischer-Tropsch Synthesis over Co Catalysts. J. Phys. Chem. C 2009, 113, 8357-8365. [CrossRef]

32. Yu, M.; Liu, L.; Jia, L.; Li, D.; Wang, Q.; Hou, B. Equilibrium morphology evolution of FCC cobalt nanoparticle under CO and hydrogen environments. Appl. Surf. Sci. 2020, 504, 144469. [CrossRef]

33. Keyvanloo, K.; Fisher, M.J.; Hecker, W.C.; Lancee, R.J.; Jacobs, G.; Bartholomew, C.H. Kinetics of deactivation by carbon of a cobalt Fischer-Tropsch catalyst: Effects of $\mathrm{CO}$ and $\mathrm{H}_{2}$ partial pressures. J. Catal. 2015, 327, 33-47. [CrossRef]

34. Zijlstra, B.; Broos, R.J.P.; Chen, W.; Oosterbeek, H.; Filot, I.A.W.; Hensen, E.J.M. Coverage Effects in CO Dissociation on Metallic Cobalt Nanoparticles. ACS Catal. 2019, 9, 7365-7372. [CrossRef]

35. Chen, P.-P.; Liu, J.-X.; Li, W.-X. Carbon Monoxide Activation on Cobalt Carbide for Fischer-Tropsch Synthesis from First-Principles Theory. ACS Catal. 2019, 9, 8093-8103. [CrossRef] 
36. Petersen, M.A.; van den Berg, J.-A.; Ciobîcă, I.M.; van Helden, P. Revisiting CO Activation on Co Catalysts: Impact of Step and Kink Sites from DFT. ACS Catal. 2017, 7, 1984-1992. [CrossRef]

37. Van Helden, P.; van den Berg, J.-A.; Weststrate, C.J. Hydrogen Adsorption on Co Surfaces: A Density Functional Theory and Temperature Programmed Desorption Study. ACS Catal. 2012, 2, 1097-1107. [CrossRef]

38. Ledesma, C.; Yang, J.; Blekkan, E.A.; Holmen, A.; Chen, D. Carbon Number Dependence of Reaction Mechanism and Kinetics in CO Hydrogenation on a Co-Based Catalyst. ACS Catal. 2016, 6, 6674-6686. [CrossRef]

39. Ledesma, C.; Yang, J.; Chen, D.; Holmen, A. Recent Approaches in Mechanistic and Kinetic Studies of Catalytic Reactions Using SSITKA Technique. ACS Catal. 2014, 4, 4527-4547. [CrossRef]

40. Otarod, M.; Happel, J.; Walter, E. Transient isotopic tracing of methanation kinetics with parallel paths. Appl. Catal. A Gen. 1997, 160, 3-11. [CrossRef]

41. Yang, J.; Qi, Y.; Zhu, J.; Zhu, Y.A.; Chen, D.; Holmen, A. Reaction mechanism of CO activation and methane formation on Co Fischer-Tropsch catalyst: A combined DFT, transient, and steady-state kinetic modeling. J. Catal. 2013, 308, 37-49. [CrossRef]

42. Van Berge, P.J.; van de Loosdrecht, J.; Visagie, J.L. Process for Producing Hydrocarbons with Cobalt Catalysts. Europe Patent EP1299503B1, 15 August 2007.

43. Van de Loosdrecht, J.; Barradas, S.; Caricato, E.A.; Ngwenya, N.G.; Nkwanyana, P.S.; Rawat, M.A.S.; Sigwebela, B.H.; van Berge, P.J.; Visagie, J.L. Calcination of Co-Based Fischer-Tropsch Synthesis Catalysts. Top. Catal. 2003, 26, 121-127. [CrossRef]

44. Borg, Ø.; Dietzel, P.D.C.; Spjelkavik, A.I.; Tveten, E.Z.; Walmsley, J.C.; Diplas, S.; Eri, S.; Holmen, A.; Rytter, E. Fischer-Tropsch synthesis: Cobalt particle size and support effects on intrinsic activity and product distribution. J. Catal. 2008, 259, 161-164. [CrossRef]

45. Carvalho, A.; Ordomsky, V.V.; Marcilio, N.R.; Khodakov, A.Y. Number and intrinsic activity of cobalt surface sites in platinum promoted zeolite catalysts for carbon monoxide hydrogenation. Catal. Sci. Technol. 2020, 10, 2137-2144. [CrossRef]

46. Weststrate, C.J.; Niemantsverdriet, J.W. Understanding FTS selectivity: The crucial role of surface hydrogen. Faraday Discuss. 2017, 197, 101-116. [CrossRef] [PubMed]

47. Ma, W.; Jacobs, G.; Das, T.K.; Masuku, C.M.; Kang, J.; Ramana, V.; Pendyala, R.; Davis, B.H.; Klettlinger, J.L.S.; Yen, C.H. Fischer-Tropsch Synthesis: Kinetics and Water Effect on Methane Formation over $25 \% \mathrm{Co} / \gamma-\mathrm{Al}_{2} \mathrm{O}_{3}$ Catalyst. Ind. Eng. Chem. Res. 2014, 53, 2157-2166. [CrossRef]

48. Bianchi, D.; Gass, J.L. Hydrogenation of carbonaceous adsorbed species on an iron/alumina catalyst, I. Experiments in isothermal conditions and exploitation by a kinetic model. J. Catal. 1990, 123, 298-309. [CrossRef]

49. Efstathiou, A.M.; Chafik, T.; Bianchi, D.; Bennett, C.O. CO chemisorption and hydrogenation of surface carbon species formed after $\mathrm{CO} / \mathrm{He}$ reaction on $\mathrm{Rh} / \mathrm{MgO}$ : A transient kinetic study using FTIR and mass spectroscopy. J. Catal. 1994, 147, 24-37. [CrossRef]

50. Couble, J.; Bianchi, D. Experimental Microkinetic Approach of the Surface Reconstruction of Cobalt Particles in Relationship with the $\mathrm{CO} / \mathrm{H}_{2}$ Reaction on a Reduced $10 \% \mathrm{Co} / \mathrm{Al}_{2} \mathrm{O}_{3}$ Catalyst. J. Phys. Chem. C 2013, 117, 14544-14557. [CrossRef]

51. Paredes-Nunez, A.; Lorito, D.; Schuurman, Y.; Guilhaume, N.; Meunier, F.C. Origins of the poisoning effect of chlorine on the $\mathrm{CO}$ hydrogenation activity of alumina-supported cobalt monitored by operando FT-IR spectroscopy. J. Catal. 2015, 329, 229-236. [CrossRef]

52. Weststrate, C.J.; van de Loosdrecht, J.; Niemantsverdriet, J.W. Spectroscopic insights into cobalt-catalyzed Fischer-Tropsch synthesis: A review of the carbon monoxide interaction with single crystalline surfaces of cobalt. J. Catal. 2016, 342, 1-16. [CrossRef]

53. Schweicher, J.; Bundhoo, A.; Frennet, A.; Kruse, N.; Daly, H.; Meunier, F.C. DRIFTS/MS studies during chemical transients and SSITKA of the $\mathrm{CO} / \mathrm{H}_{2}$ reaction over Co-MgO catalysts. J. Phys. Chem. C 2010, 114, 2248-2255. [CrossRef]

54. Cheng, Q.; Tian, Y.; Lyu, S.; Zhao, N.; Ma, K.; Ding, T.; Jiang, Z.; Wang, L.; Zhang, J.; Zheng, L.; et al. Confined small-sized cobalt catalysts stimulate carbon-chain growth reversely by modifying ASF law of Fischer-Tropsch synthesis. Nat. Commun. 2018, 9, 3250. [CrossRef] [PubMed]

55. Hibbitts, D.; Dybeck, E.; Lawlor, T.; Neurock, M.; Iglesia, E. Preferential activation of CO near hydrocarbon chains during Fischer-Tropsch synthesis on Ru. J. Catal. 2016, 337, 91-101. [CrossRef] 
56. Ojeda, M.; Li, A.; Nabar, R.; Nilekar, A.U.; Mavrikakis, M.; Iglesia, E. Kinetically Relevant Steps and $\mathrm{H}_{2} / \mathrm{D}_{2}$ Isotope Effects in Fischer-Tropsch Synthesis on Fe and Co Catalysts. J. Phys. Chem. C 2010, 114, 19761-19770. [CrossRef]

57. Ojeda, M.; Nabar, R.; Nilekar, A.U.; Ishikawa, A.; Mavrikakis, M.; Iglesia, E. CO activation pathways and the mechanism of Fischer-Tropsch synthesis. J. Catal. 2010, 272, 287-297. [CrossRef]

58. Vada, S.; Chen, B.; Goodwin, J.G., Jr. Isotopic transient study of La promotion of $\mathrm{Co} / \mathrm{Al}_{2} \mathrm{O}_{3}$ on $\mathrm{CO}$ hydrogenation. J. Catal. 1995, 153, 224-231. [CrossRef]

59. Yang, J.; Frøseth, V.; Chen, D.; Holmen, A. Particle size effect for cobalt Fischer-Tropsch catalysts based on in situ CO chemisorption. Surf. Sci. 2016, 648, 67-73. [CrossRef]

60. Peña, D.; Griboval-Constant, A.; Lancelot, C.; Quijada, M.; Visez, N.; Stéphan, O.; Lecocq, V.; Diehl, F.; Khodakov, A.Y. Molecular structure and localization of carbon species in alumina supported cobalt Fischer-Tropsch catalysts in a slurry reactor. Catal. Today 2014, 228, 65-76. [CrossRef]

61. De Pontes, M.; Yokomizo, G.H.; Bell, A.T. A novel method for analyzing transient response data obtained in isotopic tracer studies of CO hydrogenation. J. Catal. 1987, 104, 147-155. [CrossRef]

62. Van Helden, P.; van den Berg, J.A.; Ciobîcă, I.M. Hydrogen-assisted CO dissociation on the Co(211) stepped surface. Catal. Sci. Technol. 2012, 2, 491-494. [CrossRef]

63. Moodley, D.J.; van de Loosdrecht, J.; Saib, A.M.; Niemantsverdriet, J.W. Advances in Fischer-Tropsch Synthesis, Catalysts and Catalysis; Davis, B.H., Occelli, M.L., Speight, J.G., Eds.; CRC Press: Boca Raton, FL, USA, 2010; Chapter 4; pp. 49-81.

64. Sadeqzadeh, M.; Chambrey, S.; Piché, S.; Fongarland, P.; Luck, F.; Curulla-Ferré, D.; Schweich, D.; Bousquet, J.; Khodakov, A.Y. Deactivation of a $\mathrm{Co} / \mathrm{Al}_{2} \mathrm{O}_{3}$ Fischer-Tropsch catalyst by water-induced sintering in slurry reactor: Modeling and experimental investigations. Catal. Today 2013, 215, 52-59. [CrossRef]

65. Peña, D.; Griboval-Constant, A.; Lecocq, V.; Diehl, F.; Khodakov, A.Y. Influence of operating conditions in a continuously stirred tank reactor on the formation of carbon species on alumina supported cobalt Fischer-Tropsch catalysts. Catal. Today 2013, 215, 43-51. [CrossRef]

66. Costa, C.N.; Christou, S.Y.; Georgiou, G.; Efstathiou, A.M. Mathematical modeling of the oxygen storage capacity phenomenon studied by $\mathrm{CO}$ pulse transient experiments over $\mathrm{Pd} / \mathrm{CeO}_{2}$ catalyst. J. Catal. 2003, 219, 259-272. [CrossRef]

67. Rebmann, E.; Fongarland, P.; Lecocq, V.; Diehl, F.; Schuurman, Y. Kinetic modeling of transient Fischer-Tropsch experiments over $\mathrm{Co} / \mathrm{Al}_{2} \mathrm{O}_{3}$ catalysts with different microstructures. Catal. Today 2016, 275, 20-26. [CrossRef] 